\title{
Beyond reforestation: \\ An assessment of Vietnam's REDD+ Readiness
}

Do Trong Hoan and Delia Catacutan 



\section{Beyond reforestation: An assessment of Vietnam's REDD+ Readiness}

Do Trong Hoan and Delia Catacutan

Working Paper 180 


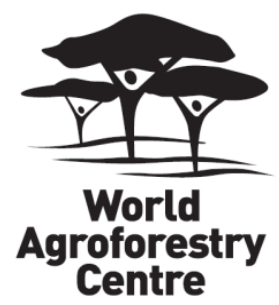

\section{Correct citation:}

Hoan DT and Catacutan D. 2014. Beyond reforestation: An assessment of Vietnam's REDD+ Readiness. Working Paper 180. Bogor, Indonesia: World Agroforestry Centre (ICRAF) Southeast Asia Regional Program. DOI: 10.5716/WP14097.PDF

Titles in the Working Paper Series share interim results on agroforestry research and practices to stimulate feedback from the scientific community. Other publication series from the World Agroforestry Centre include agroforestry perspectives, technical manuals and occasional papers.

Published by the World Agroforestry Centre

Southeast Asia Regional Program

PO Box 161, Bogor 16001

Jawa Barat

Indonesia

Tel: +622518625415

Fax: +62 2518625416

Email: icraf-indonesia@cgiar.org

Website: http://worldagroforestry.org/regions/southeast_asia

(C) World Agroforestry Centre 2014

\section{Disclaimer and copyright}

The views expressed in this publication are those of the author(s) and not necessarily those of the World Agroforestry Centre. Articles appearing in this publication may be quoted or reproduced without charge, provided the source is acknowledged. All images remain the sole property of their source and may not be used for any purpose without written permission of the source. 


\section{About the authors}

Do Trong Hoan is a research officer at the World Agroforestry Centre Viet Nam. He holds a Master degree in Environmental Science and Technology from Pohang University of Science and Technology, Republic of Korea. His research interests include greenhouse gas emissions' mitigation through land-based practices and bioprocesses, trade-off analyses, REDD+, payments for environmental services and participatory land-use planning. He is currently managing Secured Landscapes project activities in Viet Nam.

Delia Catacutan is senior social scientist at the World Agroforestry Centre Viet Nam, with more than 10 years' experience in policy and institutional research in integrated natural resource management. Dr Catacutan is also the Centre's country coordinator of the Viet Nam program and focal point for gender research and capacity building. She has extensive experience working in interdisciplinary research projects, including smallholders' incentives for ecosystem services, linking knowledge with action, institutional innovations, collective action and property rights, and technology adoption in Asia and Africa. She was a post-doctoral fellow at the Sustainability Science Program at Harvard University's Center for International Development. She holds a PhD in Natural and Rural Systems Management from the University of Queensland, Australia. 



\section{Abstract}

As the Government of Vietnam is showing great interest and commitment to REDD+, it is important to examine the country's 'readiness' based on the functions that need to be fulfilled. This paper reports on rapid REDD+ readiness assessment conducted through documents' review, surveyquestionnaires, in-depth interviews and round-table discussions with Vietnam's National REDD Network. It was found that Vietnam's reforestation experience does not foretell REDD+ readiness. Its readiness level as perceived by in-situ stakeholders only ranged from low to medium across all functions. For the country to move beyond its current state of REDD+ readiness, activities should focus on indicators where it is weak while strengthening those that are already advancing, and postreforestation issues should be resolved. Failure to address them will mean an uphill implementation of REDD+. The paper concludes with specific recommendations for Vietnam to advance its REDD+ readiness that might be useful for other countries that share similar issues with Vietnam.

Keywords: climate change policies, forest carbon, REDD, REDD+ readiness 



\section{Content}

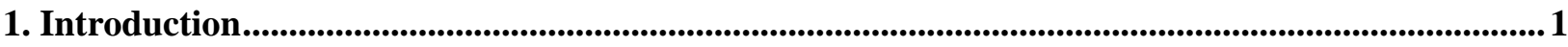

2. Methodology …................................................................................................................................................ 3

2.1. REDD+ Readiness Assessment Framework …......................................................................... 3

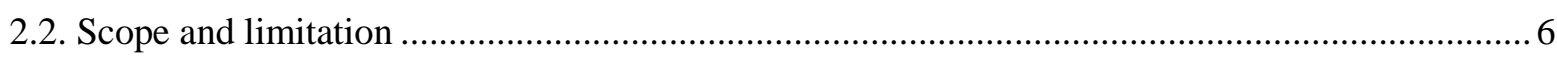

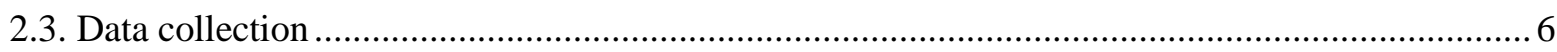

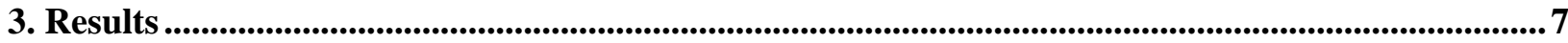

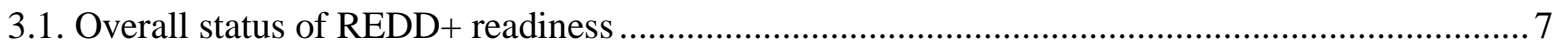

3.2. REDD+ Readiness Assessment by Function .......................................................................

3.3. Differences between GO and NGO assessment of REDD+ readiness ....................................... 12

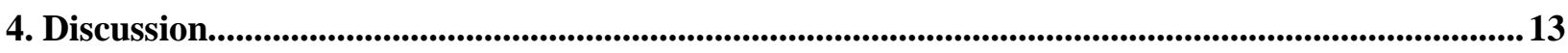

4.1. REDD+ readiness and drivers of deforestation and degradation .......................................... 14

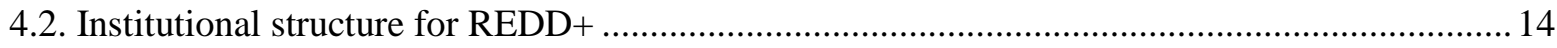

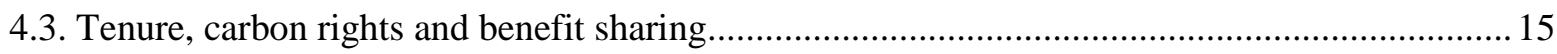

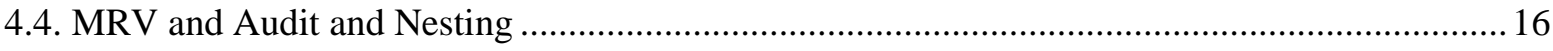

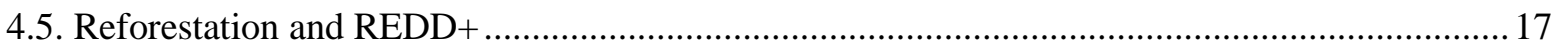

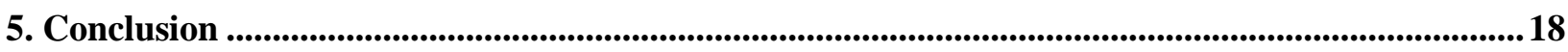

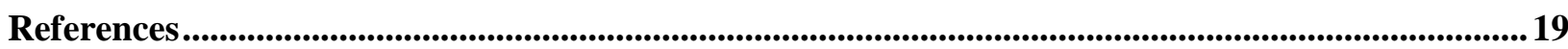




\section{List of Figures}

Figure 1. Forest changes in Vietnam (2000-2010) …….................................................................... 2

Figure 2b. Elements of national REDD+ (Scheyvens, 2010) …………………...................................... 4

Figure 2a. Elements of national REDD+ (UN-REDD and FCPF, 2012)................................................. 4

Figure 3. REDD+ Readiness Assessment Framework (Minang et al., this issue) ................................. 5

Figure 4. Overall assessment of REDD+ Readiness............................................................................ 8

Figure 5. Interim Institutional Structure for REDD+ in Vietnam ...................................................... 11

Figure 6. GO and NGO assessment of REDD+ readiness ............................................................... 13

\section{List of Tables}

Table 1. Rating scale used in assessing REDD+ readiness functions and indicators ...........................

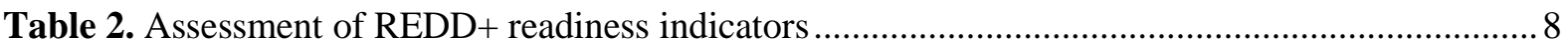




\section{Introduction}

Since losing between 33\% to more than half of its forest cover from 1943 to early 1990s (Collins, Jeffrey \& Timothy, 1991; De Koninck, 1999; Rambaldi, Bugna \& Geiger, 2001; Sunderlin, \& Huynh, 2005; Scheyvens, Hyakumura \& Seki, 2007; Meyfroidt \& Lambin, 2008), the Government of Vietnam has been implementing policies and programmes aimed at curbing deforestation and accelerating reforestation. The revised Land Law of 1993 can be considered as Vietnam's landmark in forestland allocation that paved the way to progressive policy reforms in the forestry sector. Building on predecessor reforestation projects, Decision 661/QD-TTg, otherwise known as Programme 661, is by far, the largest reforestation programme in Vietnam. The Programme which began in 1998 aimed to reforest five million hectares, not only to achieve $43 \%$ forest cover by 2010 , but also to create jobs and increase rural incomes, achieve socio-political stability, and transform forestry into an economically vibrant sector through sustainable supply of wood, pulp and timber. The Programme mobilized the entire government-led forestry sector and local governments to ensure success.

Ten years after the implementation of Programme 661, the Ministry of Agriculture and Rural Development (MARD) reported an increase in forest cover from 26\% in 1994 to 38\% in 2006 (Dinh, \& Dang 2008). Several authors such as Meyfroidt \& Lambin (2009) also reported a steady growth in forest cover from about $24.7 \%$ in 1992 to about $38.2 \%$ in 2005. By 2010, the reported forest cover in Vietnam was 39.5\% (MARD, 2011) with a net increase of $18.6 \%$ in 10 years (2000-2010) (Figure 1). Subsequently, Vietnam received global attention for making it to the latter stage of forest transition (Meyfroidt \& Lambin, 2008, 2011; Angelsen et al., 2009; Mertz et al., 2012). However, concerns about forest quality remain, as the country's forests have been transformed into young and poorly stocked forests (Lambin \& Meyfroidt, 2010; Socialist Republic of Vietnam [SRV], 2011). The government was also criticized for its top-down approach in the design and implementation of reforestation programmes (Castella, Gevraise, \& Novosad, 2005; Sunderlin \& Huynh, 2006; Pham, Moeliono, T.H. Nguyen, H.T. Nguyen \& Vu, 2012), and for its lack of mechanism for performancebased benefit sharing (UN-REDD, 2010). Vietnam has been also criticized for protecting its forest while exporting deforestation to neighboring countries for nearly two decades (1987-2006). This strategy has reportedly contributed 39\% of the volume of wood regrowth of Vietnam's forests (Meyfroidt \& Lambin, 2009). There are other negative environmental and social consequences of Vietnam's strategy, which are often overlooked by many observers (McElwee, 2012). 


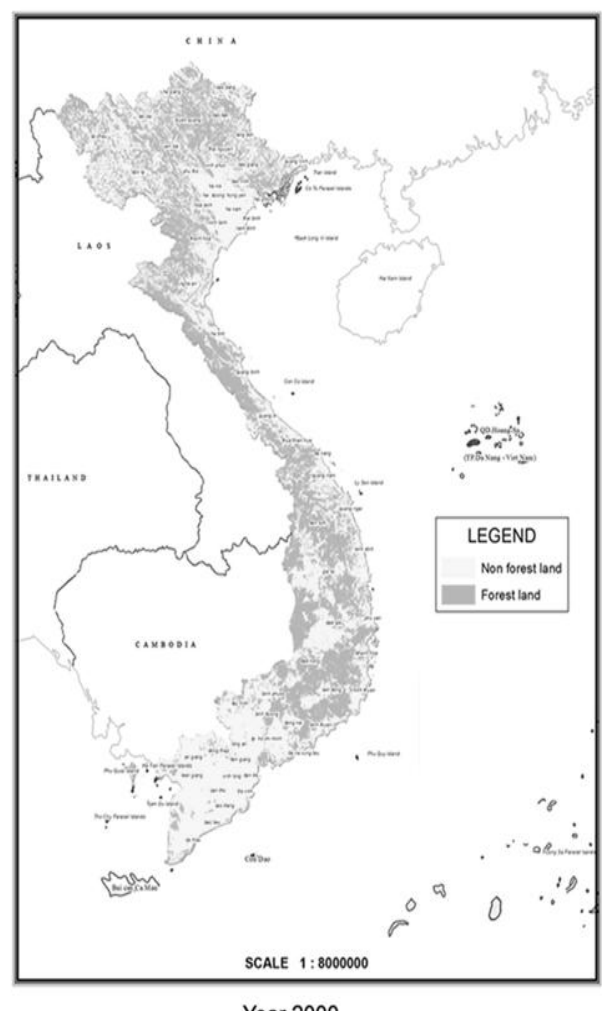

Year 2000

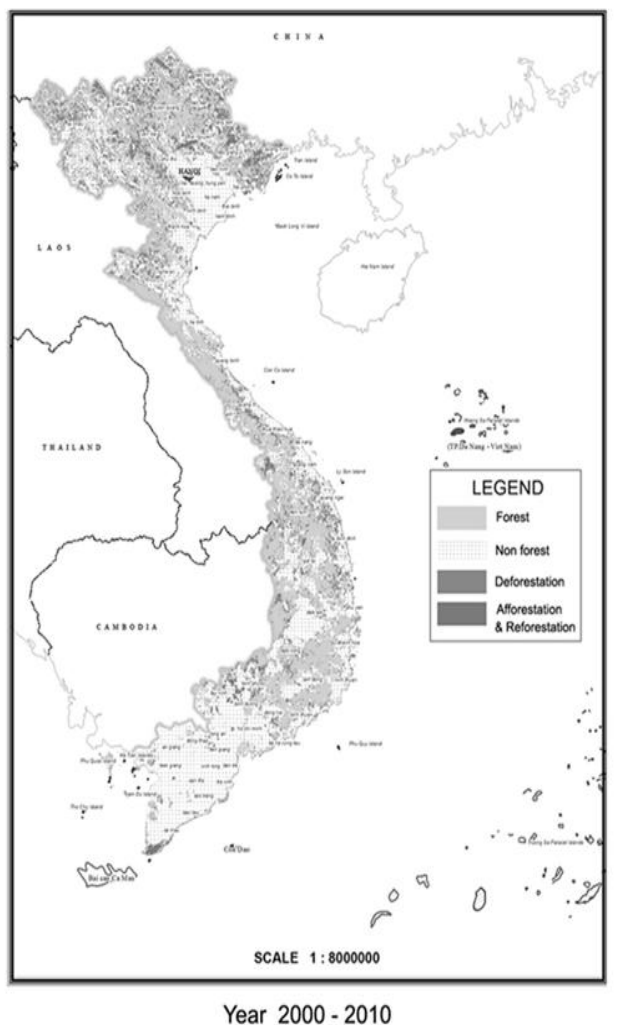

Year $2000-2010$

Figure 1. Forest changes in Vietnam (2000-2010)

Forest changes in Vietnam are a result of mixed causes. On one hand, the direct drivers of deforestation and degradation are agriculture expansion, infrastructure development, unsustainable logging and forest fires, while population and migration, weak forest management capacity, and limited funding for forest protection are indirect drivers (De Koninck, 1999; SRV, 2008; Hoang et al., 2010; Pham et al., 2012). Reforestation on the other hand, is driven by economic and political responses to forest and land scarcity, economic growth, land privatization, land-use zoning, food crop intensification, market liberalization (Sunderlin \& Huynh, 2005; Meyfroidt \& Lambin, 2011), and science and technology development (De Jong, Do \& Trieu, 2006). Addressing these drivers through comprehensive forest conservation and management under a REDD+ framework is crucial to success.

Despite the ambivalence in Vietnam's reforestation and forest protection strategies, it was, in 2008, chosen by the Forest Carbon Partnership Facility (FCPF) among a number of countries to be given support, and was again, in 2009 selected as the first pilot country of the United Nations Collaborative Programme on REDD (UN-REDD) to implement the following activities: (i) building a robust policy platform through preparation of a National REDD Programme (NRP); (ii) establishing a coordination and steering mechanism for REDD readiness; and (iii) preparing a national REDD infrastructure, building capacity at national and subnational levels and establishing a national accounting system. Subsequently, Vietnam was recognized as amongst few countries that have gained momentum towards the $2^{\text {nd }}$ phase of REDD Readiness (UN-REDD \& FCPF, 2012). However, several issues remain, and questions arise whether such recognition actually depicts reality.

To address this question, we assessed Vietnam's 'readiness' REDD+ using the Readiness Assessment Framework suggested by Minang et al., (in this issue), which is described in the methods section below. The assessment was guided by the following questions: (i) how do stakeholders in Vietnam's 
National REDD Network (NRN) assess the country's REDD+ readiness?; (ii) do government and non-government members of NRN differ in their assessment of Vietnam's REDD+ readiness?; and (iii) what recommendations can be made for the government to be fully ready to implement its NRP?

Our assessment is nowhere complete or comprehensive, but the framework used is more practical as it embodies the main functions of REDD+ design and implementation, making the assessment more direct and concrete. However, it was prudent for us to reflect upon the rich experience of Vietnam's reforestation, as this has made an important mark in the history of its forest sector.

\section{Methodology}

\subsection{REDD+ Readiness Assessment Framework}

While significant amount of funding has been made available for readiness activities over the last few years, there is lack of criteria and guidelines for the evaluation of the ReadinessPackage (R-Package) (Lang, 2011). Funding for REDD+ readiness are generally used for these building blocks: (i) preparation of national REDD+ strategies; (ii) stakeholders' engagement and consultation; (iii) filling the gaps of institutional structures and national policies; (iv) designing/implementing Monitoring, Reporting and Verification (MRV) systems; (v) development of national systems for determining baselines and Reference Emissions Levels (RELs); (vi) development of a transparent, equitable and accountable benefit sharing mechanisms; (vii) developing safeguards and grievance mechanisms to protect the interests of forest communities and the poor; and (viii) clarifying national land, forest and carbon tenure rights. Both the UN-REDD and FCPF (2012) developed a framework for REDD+ Readiness at country level with six components that is consistent with currently used R-PP template and the UN-REDD Programme's Support to National REDD+ Action - Global Programme Framework 2011-2015 (Figure 2a). Similarly, Scheyvens (2010) developed a six-element conceptual framework for REDD+ readiness based on discussions under United Nations' Framework Convention on Climate Change (UNFCCC) (Figure 2b). 


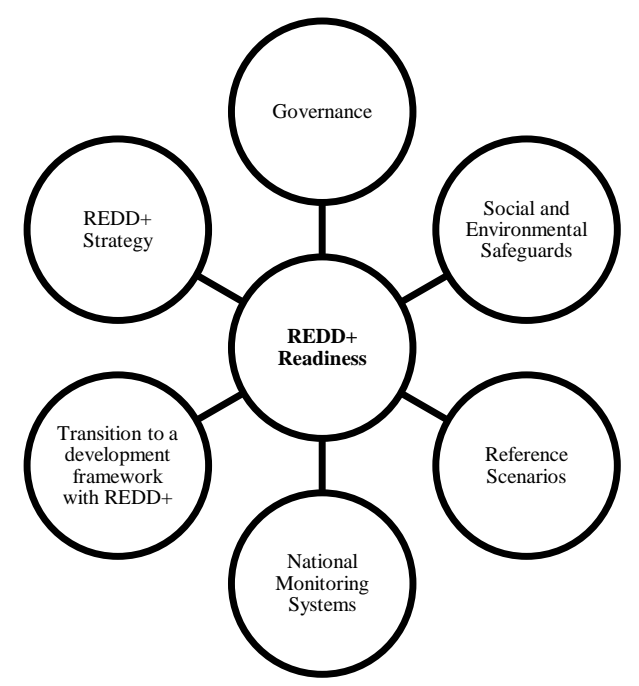

Figure 2a. Elements of national REDD+ (UN-REDD and FCPF, 2012)

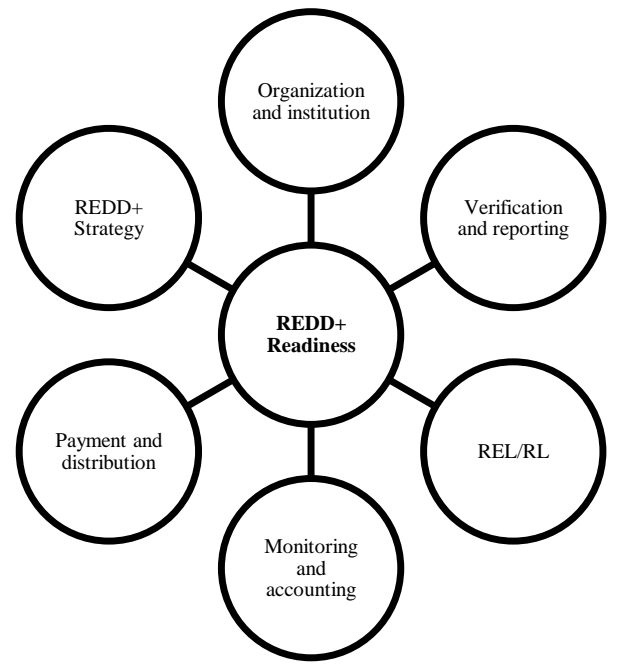

Figure 2b. Elements of national REDD+ (Scheyvens, 2010)

Moreover, Simula (2010) merged the cost requirement components of R-PP and National Programme Documents for UN-REDD into four functional categories: (i) Organization, consultation and management of the REDD+ process; (ii) REDD+ Strategy; (iii) Reference scenario/level; and (iv) Monitoring system. Lastly, Parker (2012) listed seven elements of REDD+ in two umbrella domains. The first domain is legal and institutional framework, which has management and coordination, stakeholder engagement and participation, rights and tenure, and compliance as elements. The second is methodological framework with elements such as reference levels, safeguards, and MRV.

Although the above frameworks are similar and overlapping, there is no single framework or criteria used in various readiness studies. This could be partly explained by differences in stakeholders' understanding and expectations of REDD+ readiness across many countries and the expertise of readiness evaluators and their roles in the global REDD+ processes (Simula, 2010; Westholm, 2010; UN-REDD and FCPF, 2012; International Sustainability Unit [ISU], 2012). In short, REDD+ readiness definition is diverse and evolving (Parker, 2012); hence, there is no universal definition of who is ready for REDD+. It should be considered that although countries are utilizing similar readiness funding sources, they are at different stages of readiness (ISU, 2012; UN-REDD and FCPF, 2012) and have different their own priorities (Johns, Johnson \& Greenglass, 2010). Some authors including Mayers, Maginnis, \& Arthur (2010) and Mattson, Persson, Ostwald, \& Nissanka (2012) scrutinized readiness at the country level by focusing on the most practical need to national circumstance. Although this approach is practical, it was difficult to compare the state of readiness of the countries involved. It appears that despite many REDD+ assessments, little was discussed about how 'readiness' activities actually relates to the countries' capacity as well as how stakeholders were consulted during the process.

Minang et al. REDD+ readiness framework, which comprised six functions, 9 sub-functions and 27 indicators (Figure 3) was used for this assessment, for several reasons: (i) it adds political and economic dimensions into existing readiness thinking based on technical, institutional and policy conditions; (ii) it categorizes readiness elements into domains, sub-domains and indicators with narrative descriptions; (iii) it is largely scalable and applicable to other environmental services (than emission reduction alone) with modification of indicators as relevant; and (iv) unlike most readiness 
assessments in the literature which are based on subjective evaluations of consultants or authors, the framework captures perspectives of national stakeholders who are directly involved in REDD+ readiness processes. A brief description of each function is given below.

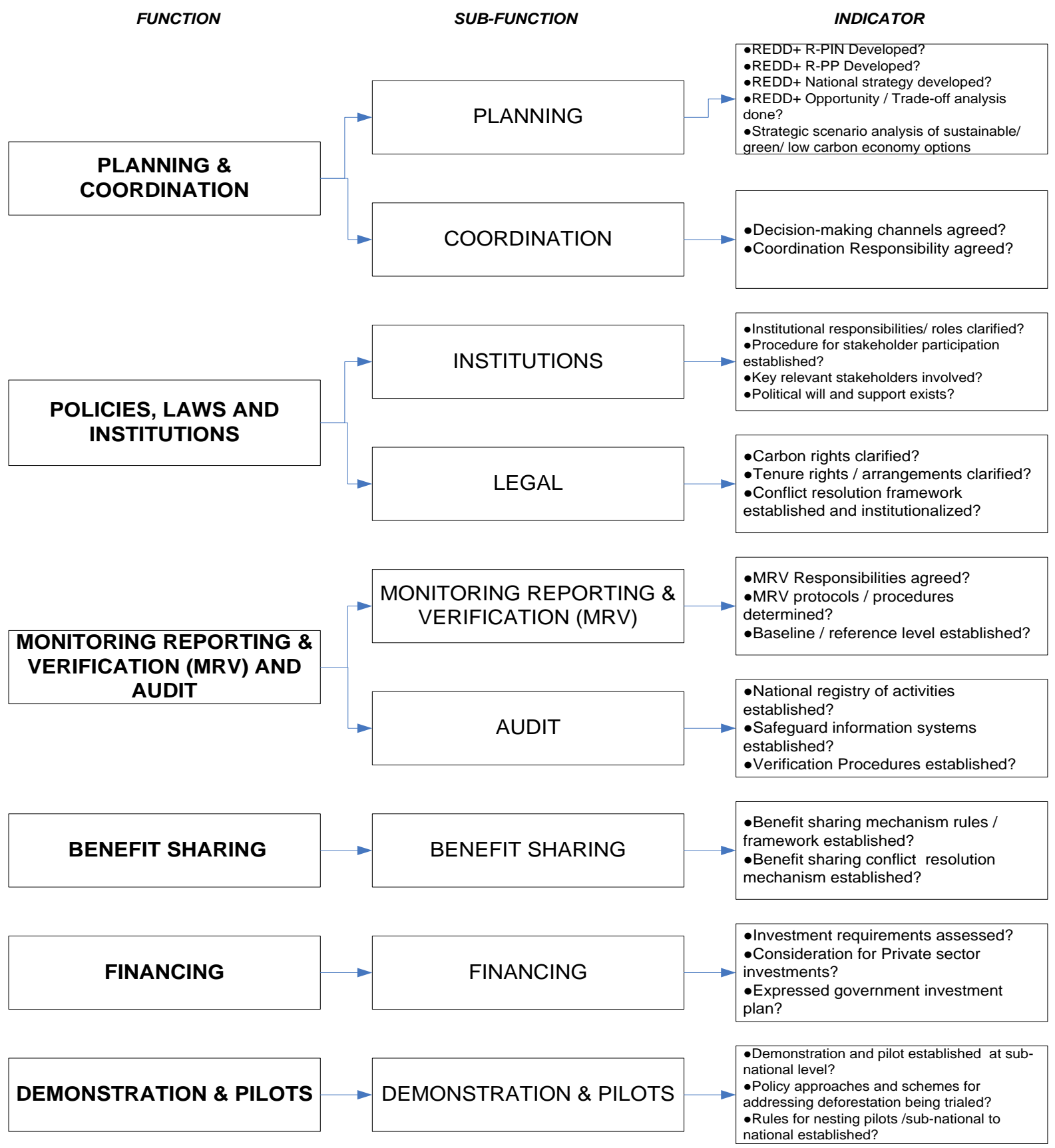

Figure 3. REDD+ Readiness Assessment Framework (Minang et al., this issue)

Planning and Coordination. Participatory approaches are used in planning and coordination, and necessary assessments of potential costs, benefits and trade-offs, as well as strategic and operational planning for REDD are done.

1. Policies, Laws, and Institutions. Among the critical aspects of a policy and legal framework that are necessary in a REDD+ mechanism are institutions, participation and consultation rules, 
process for project approval, funding rules, management of a national pool or buffer, rights to forests and carbon, taxes and state payments, benefit sharing rules and forest definitions.

2. Monitoring, Reporting and Verification (MRV) and Audit. A national MRV system include key steps such as assessing the data infrastructure, assigning responsibility for MRV in terms of an institution agreeing on rules for, and setting up a baseline or reference emission level and protocols and procedures for MRV.

3. Financing. REDD+ could not depend on global financing alone. Countries involved or interested in REDD+ mechanism should leverage internal funding. Diversifying and coupling funding sources, including facilitating private sector contributions, enabling government investments, and seeking efficient ways of managing REDD projects enable financial sustainability for REDD+.

4. Benefit Sharing. Equitable, transparent and effective benefit sharing mechanisms are necessary for REDD+ to succeed. Such mechanisms should look at rules and modalities for distribution and conflict resolution. Rules established for a benefit sharing mechanism include formula for allocating benefits, eligibility for benefits, maintaining transparency, timing of payment, and responsibilities of actors in the benefits sharing process at multiple levels.

5. Demonstration and Pilots. Demonstration and pilots at all levels have been recognized and supported as part of REDD+ readiness process. These pilots foster learning-by-doing and enable adaptive management. Demonstrations are largely at subnational level, while pilots could entail national level systems.

\subsection{Scope and limitation}

NRN members referred to, as 'in situ' stakeholders in this paper, assessed Vietnam's REDD+ readiness using 19 out of 27 indicators. The assessment centered on readiness activities financed through the UN-REDD Programme and the FCPF, although reference was also made to activities implemented by international, national or local non-government organizations in the country. Our assessment is neither complete nor comprehensive, but our recommendations might help the country to move towards REDD+ implementation.

\subsection{Data collection}

Data were collected through documents review, round table discussion, self-administered questionnaires, and in-depth interviews from July to December 2012.

\section{Review of documents}

The following documents were reviewed: (i) national programmes/strategies; (ii) UN-REDD Programme and FCPF reports; and (iii) reports from the Vietnam Administration of Forestry (VNFOREST) and NRN, and the findings aided in explaining the interview results.

\section{Round-table discussion}

A round table discussion was facilitated with nine NRN members and NGO staff involved in REDD+ related projects on July 2012 to (i) discuss the REDD+ readiness assessment framework; (ii) pre-test the questionnaire; and (iii) draw preliminary insights on Vietnam's REDD+ readiness.

\section{Self-administered questionnaire}

A self-administered questionnaire was designed to assess REDD+ readiness functions and indicators using the rating scale shown in Table 1 . The questionnaire was electronically circulated to the NRN, 
of which, 14 were retrieved, representing about $25 \%$ of its membership. The respondents were grouped according to their institutional affiliations. The first group is government organization (GO), comprising government (5) and donor agency (2) representatives. The second group comprised NGO staff involved in REDD+ projects (7). Data were analyzed using descriptive statistics such as frequencies and means.

Table 1. Rating scale used in assessing REDD+ readiness functions and indicators

\begin{tabular}{lll}
\hline Rating & Description & Conditions \\
\hline $0-1$ & Low/Poor & Indicator is not yet discussed \\
\hline$>1-2$ & Medium/Fair & Indicator is being discussed \\
\hline$>2$ & High/Good & Indicator or issues around it are agreed in principle \\
\hline 3 & Very High/Very Good & Rules, laws or policy decisions already exist \\
\hline
\end{tabular}

\section{In-depth interviews}

Seven out of 14 respondents were subjected to in-depth interviews, of which, three were from the GO and four were from the NGO group. The interviews were aimed to elicit more information, and follow up specific issues.

\section{Results}

\subsection{Overall status of REDD+ readiness}

In the following order, respondents rated Planning and Coordination, Demonstration/pilots, Benefit Sharing, and MRV and Audit functions, only fairly (>1-2) and low/poorly (0-1) for Policy/Legal and Institutional Framework and Financing (Figure 4). Of 19 indicators, three were rated high, eight medium, and another eight were rated low (Table 2). Despite concerns and criticisms against them, it appears that the REDD Readiness Plan Idea Notes (R-PIN), Readiness Preparation Proposal (R-PP) and National REDD Strategy, and policies to address deforestation out did 16 indicators, although their mean value was less only than two (>2).

In sum, the six readiness functions were rated only fairly/medium (>1-2), which means that Vietnam's readiness preparations might take longer than expected. Low rated indicators such as trade-off analysis, nesting rules, tenure and carbon rights, and REDD+ conflict resolution framework are crucial to REDD+ implementation, and should be the focus of readiness activities. Failure to address them would mean an uphill implementation of REDD+ in Vietnam. A detailed discussion of the assessment is provided below. 


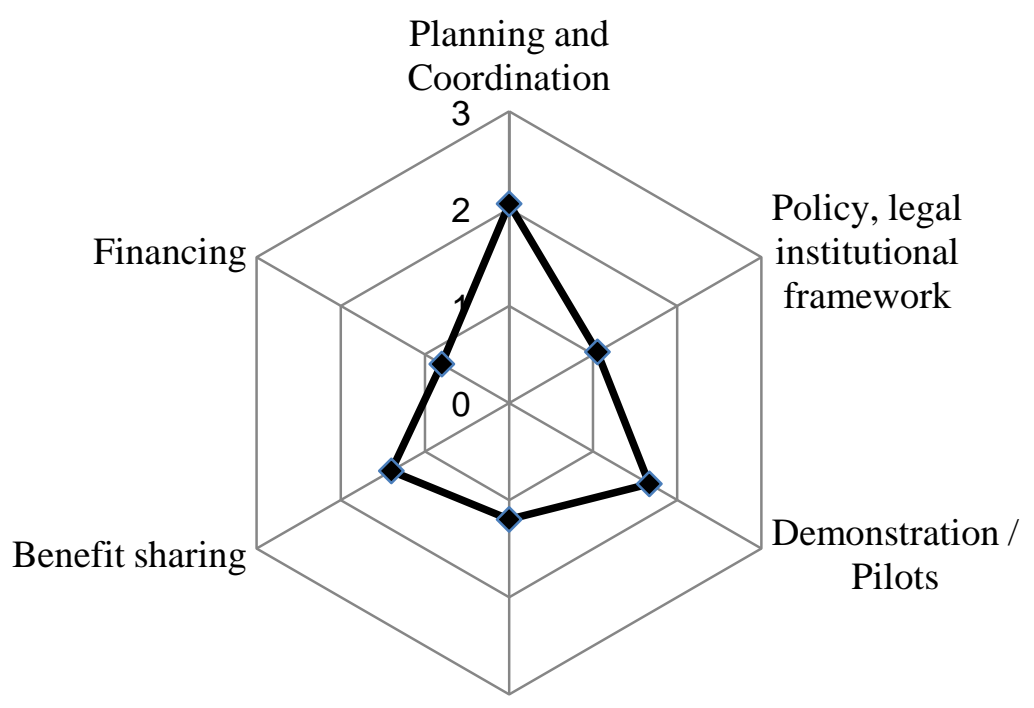

MRV and audits

Figure 4. Overall assessment of REDD+ Readiness

Table 2. Assessment of REDD+ readiness indicators

\begin{tabular}{llll}
\hline Function & Indicators & Mean $(\mathbf{n}=\mathbf{1 4})$ & Readiness \\
\hline P \& & REDD RPIN, RPP & 2.57 & High \\
\hline P\&C & National REDD strategy & 2.50 & High \\
\hline D\&P & Policy approaches and schemes for decrease deforestation & 2.07 & High \\
\hline D\&P & Demonstration and pilot established at subnational level & 1.86 & Medium \\
\hline P\&C & Decision-making channels & 1.79 & Medium \\
\hline BS & BSM framework RULES & 1.64 & Medium \\
\hline PL\&l & Institutional responsibilities & 1.36 & Medium \\
\hline MRV\&A & MRV responsibilities & 1.36 & Medium \\
\hline PL\&I & Procedure for stakeholder participation & 1.14 & Medium \\
\hline MRV\&A & MRV protocols/procedures & 1.14 & Medium \\
\hline MRV\&A & Baseline/reference level & 1.07 & Medium \\
\hline P\&C & Opportunity cost/trade off analysis & 0.93 & Low \\
\hline MRV\&A & Safeguard info system & 0.93 & Low \\
\hline BS & BSM conflict resolution & 0.86 & Low \\
\hline D\&P & Rule for nesting & 0.71 & Low \\
\hline F & Financial investment requirements & 0.64 & Low \\
\hline PL\&l & Tenure carbon rights and contractual procedures & 0.50 & Low \\
\hline MRV\&A & National registry & 0.50 & Low \\
\hline PL\&I & REDD conflict resolution framework & 0.29 & Low \\
\hline & & & \\
\hline
\end{tabular}

Note: P\&C: Planning and Coordination; PL\&l: Policies, Laws and Institutions; MRV\&A: Monitoring, Reporting, Verification and Audits; D\&M: Demonstration and Pilots; BS: Benefit Sharing; F: Financing. 


\subsection{REDD+ Readiness Assessment by Function}

\subsubsection{Planning and Coordination}

Readiness in terms of the National REDD+ Action Programme (NRAP) (National REDD Strategy in many international documents), R-PIN and R-PP was rated medium, while opportunity cost analysis received a lower rating. The NRAP, which was approved by the Prime Minister in June 2012 is part of the National Climate Change Strategy and National Action Plan on forest protection and development (2011-2020). However, NGO respondents were concerned about the lack of consultation and participation of relevant stakeholders in developing the above documents. In terms of opportunity cost analysis at subnational level, the UN-REDD Programme (UN-REDD, 2011a) has already provided a guideline, but the Vietnam REDD Office (VRO) encountered delays in implementing it, and there were concerns that the VRO's technical expertise on this aspect may be lacking.

The establishment and clarification of REDD+ decision-making channel is rated medium (1.79) since it was part of the establishment of the National REDD Steering Committee (NRSC). However in reality, the decision-making channel for REDD+ in Vietnam has a lot of nuances. First, the Prime Minister is the only person who makes major decisions over REDD+; no decision-making channel exist at subnational level, except for the REDD+ pilot province in Lam Dong. Second, pursuant to guideline No. 282/VPCP-QHQT issued by the Prime Minister, MARD through Decision 39, created the NRSC to formulate and implement Vietnam's REDD+ Programme. The fact that the NRSC was constituted by MARD is strategic, but its structure and mandate suggest a decision-making process that is concentrated only within MARD, although it is has to collaborate with relevant Ministries and local agencies to facilitate inter-sectoral/provincial REDD+ design and implementation. The problem is that, the weakness of MARD's forestry sector in coordinating other Ministries is commonknowledge, leading to doubts as to the ability of the NRSC to attract non-forest sectors to REDD+.

\subsubsection{Demonstration/Pilots}

Respondents' assessment of demonstration/pilots came next to planning and coordination (>1-2) due to past and ongoing government programs, and the number of REDD+ pilot projects in Vietnam. Two of Vietnam's national programs, namely Programme 661 and Payment for Forest Environmental Services (PFES) ${ }^{(\mathrm{i})}$ were identified as major policies that provide financial incentives to poor communities and households for forest protection and development. Several initiatives follow sought such as Programme 147 and Forest Protection and Development Strategy (2006-2020). However, despite their good intentions, these programs have their share of weaknesses (Pham et al., 2012), which concerns NGO respondents the most. The NGO group expressed deep concerns on the way national reforestation projects were implemented - they are of strong opinion that the current forest management regime is indecisive when it comes to performance-based rewards, forest and carbon rights, benefit sharing and conflict resolution.

Furthermore, it was recognized that most pilot projects are implemented by international organizations such as the Japanese International Cooperation Agency (JICA), the Netherlands Development Agency (SNV), German Technical Cooperation (GTZ), and Flora and Fauna International (FFI) to name a few. They focused on feasibility assessment, carbon mapping, trade-off and tenure analysis, testing REDD+ design, community forestry development, and piloting free and prior inform consent (FPIC) process. These projects have been reported to the STWG, but

\footnotetext{
(i) Decision 380 and Decree 99/2010 of the Government of Vietnam on Payment for Forest Environmental Services
} 
respondents were unsure if those reports were actually used to inform the NRAP design, considering the informal representation of the STWG within the NRN and NRSC structures. Furthermore, respondents were dissatisfied that REDD+ pilots are still in form of official development assistance targeting REDD readiness, than dealing with carbon offsets.

\subsubsection{Benefit Sharing}

Benefit sharing was also rated fairly after demonstration/pilots (Figure 4). This assessment seems right, as Vietnam is amongst very few countries that has embedded REDD+ benefit sharing into its policies (Pham et al., 2013). The UN-REDD Programme funded several studies on national Benefit Distribution System (BDS) in line with international standards and appropriateness to local and national contexts. As a result, 17 Policy Decisions for REDD+ BDS have been identified (UN-REDD, 2010). However, amongst 17 policy decisions, only the 'classification of REDD+ revenues and creation of REDD+ funding' was addressed in the NRAP, where creating a separate 'branch' for REDD+ funds within the Forest Protection and Development Fund (FPDF) was proposed.

Despite the eminence of these policy decisions, respondents were concern that without a conflict resolution mechanism, the government will in the end, use the BDS employed by Programme 661 and PFES, juxtaposing the guidelines that have already been developed by the NRSC. Respondents further highlighted the need to resolve forest and carbon rights issues, as well as create an independent monitoring channel as a prerequisite for REDD+ BDS. Not to mention carbon rights, land and resource rights have always been a challenge even for PFES since absence of forestland tenure or resource rights prevents local people from opening a bank account or registering land ownership. This concern corroborates with Wertz-Kanounnikoff \& Kongphan-Apirak (2009) who found PES an option hardly feasible especially if formal tenure rights (including to carbon) are required. In essence, the bottleneck for Vietnam's REDD+ BDS lies in the weakness of its land tenure and property rights system.

\subsubsection{MRV and Audits}

MRV and Audit is the least developed amongst four functions that were rated fair/medium by respondents. The STWG-MRV was first established to help the government address the complexity in developing a REDD+ compatible MRV system. Discussions under the STWG-MRV were thought to be substantive, with the highest number of meetings held compared to other STWGs (Pham et al., 2012). MRV is also considered a core component of the NRAP. Nevertheless, such a national system is likely to take longer to evolve to the level where REDD+ can be implemented with accuracy (Peskett and Baukahaus, 2009).

The most significant output of the STWG-MRV is the draft MRV Framework document with reference to Safeguards Information and Monitoring of Policies and Measures (UN-REDD, 2011), which outlines the institutional arrangement of Vietnam's MRV. For this reason, respondents rated this indicator medium (1.36) (Table 2). MRV responsibilities were given to the NRSC, Forest Planning and Inventory Institute (FIPI) and the General Department of Land Administration (GDLA), particularly on national carbon inventory and land monitoring. In addition, the National Office for Climate Change and Ozone Protection (NOCCOP) is tasked to compile GHG inventories including REDD+ emissions and removals. MRV protocols and analyses of capacity gaps were also described in the document. However, an important aspect that was missing in the MRV framework, which was highlighted by some respondents is a mechanism to engage local communities in the MRV process. 
A number of national safeguards exist that can be incorporated into REDD+, including the Law on Environmental Protection (2005), Law on Biodiversity (2008), National Assembly's Ordinance on Plant Varieties (2004), National Assembly's Ordinance on Grassroots Democracy (2007), Decree 29 on Strategic Environmental Assessment (2011), Amended Law on Anti-corruption (2012), and most recently, Law on Grassroots Reconciliation (2013). However, NRN respondents do not consider the above as REDD+ safeguards, and instead, recommended to develop a specific REDD+ safeguards system. Nevertheless, recognition of customary laws of ethnic minorities is still a gap in current social safeguards and, as recommended by most interviewees, should be legally recognized. Meanwhile, the establishment of Safeguards Information System (SIS) for REDD+ did not progress at the pace expected by respondents; hence, it is much more behind among other indicators.

\subsubsection{Policy, Legal and Institutional Framework}

Policy, Legal and Institutional Framework is at the bottom two of the six functions (0-1) (Figure 4). Within this function, clarification of institutional responsibilities was fairly assessed (medium), which adequately conforms to efforts of the government and other stakeholders to create an institutional structure for REDD+ (Figure 5); however, respondents reiterated that the bottleneck of this function, lies in addressing tenure and carbon rights and conflict resolution (Table 2 above).
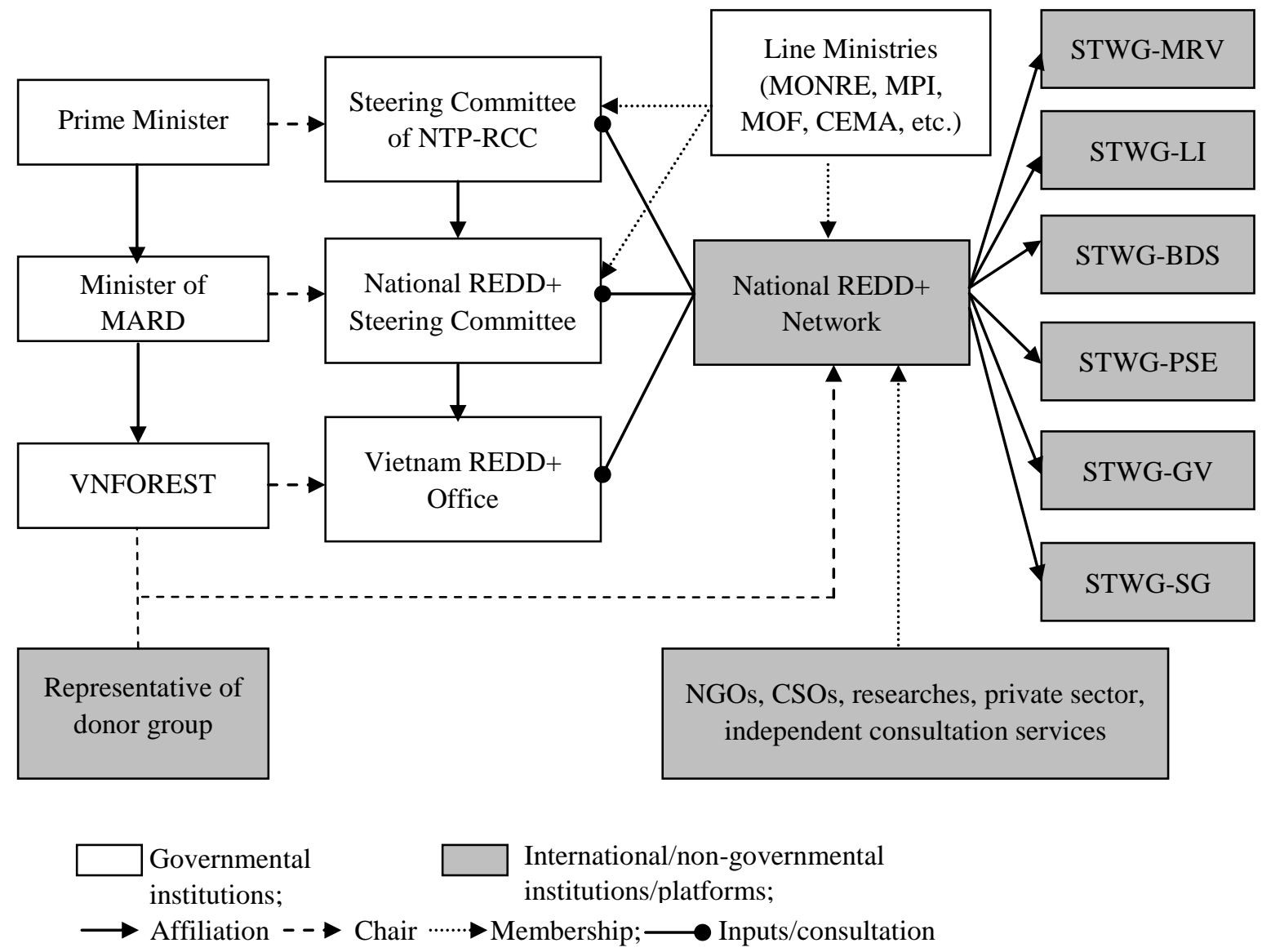

STWG: Sub-technical Working Group; MRV: Monitoring, Reporting and Verification; LI: Local implementation; BDS: Benefit distribution system; PSE: Private sector engagement; GV: Governance; SG: Safeguards; MONRE: Ministry of Natural Resources and Environment, MPI: Ministry of Planning and Investment; MOF: Ministry of Finance; CEMA: Committee of Ethnic Minority Affairs

Figure 5. Interim Institutional Structure for REDD+ in Vietnam 
Vietnam's REDD+ institutional structure is quite comprehensive. The Prime Minister brings the notion of political commitment to REDD+, with MARD as its executive arm. By virtue of MARD Decision 39, VNFOREST in 2011, which is in charge of national forest administration created both the NRSC and VRO. At the same time, the NRN was created as a flexible component of the REDD+ structure, to provide a forum for stakeholders to discuss and exchange information and advocate for a REDD+ policy. With six STWGs, the NRN is currently co-chaired by VNFOREST and a Norwegian government representative (the major donor of REDD+ in Vietnam) (Figure 5 above).

On one hand, respondents confirmed the effectiveness of the STWGs in creating a platform for REDD+ discussions, and cited the lack of participation of other relevant stakeholders such as indigenous peoples and media groups, on the other hand. This helped to explain the relatively low rating given to 'procedure of stakeholder participation' (Table 2 above).

Moreover, the NRSC had several important tasks, of which, one is to direct the formulation and implementation of the Vietnam REDD+ Programme. It also has to collaborate with relevant Ministries and local organizations to effectively coordinate an inter-sectoral--provincial implementation of REDD + . However, the weak coordination track record of MARD's forestry sector has long been observed (Hoang et al, 2010; Pham et al., 2012; UN-REDD, 2012), creating doubts on the NRSC's ability to effectively engage non-forest actors into REDD+.

Furthermore, the assessment for 'decision-making channel' was <2. It could be because only the Prime Minister decides on major aspects of REDD+ and no other decision-making channel exists at the sub-national level except at the UN-REDD+ pilot province in Lam Dong.

\subsubsection{REDD+ Financing}

Financing was lowest among six functions (Figure 4). This is unsurprising since the fund-based approach is by far, the most widely pursued approach by many REDD+ implementers in Vietnam. Efforts were made to map donors and engage the private sector to meet the financial requirements of REDD+. However, since there was no comprehensive assessment of the funding requirements of REDD+, respondents wondered as to how the budget was determined. The figure was thought to have been estimated based on donor committed funding rather than real needs. Unlike Programme 661, the government has also not leveraged substantial funding for REDD+.

\subsection{Differences between GO and NGO assessment of REDD+ readiness}

Differences between GO and NGO assessment of readiness were found in Policy/legal/institutional framework, Financing, Benefit Sharing, MRV and Audits, albeit, the difference was very narrow for Planning/Coordination and Demonstration/Pilots (Figure 6), indicating that both groups agree on their assessment of the two. 


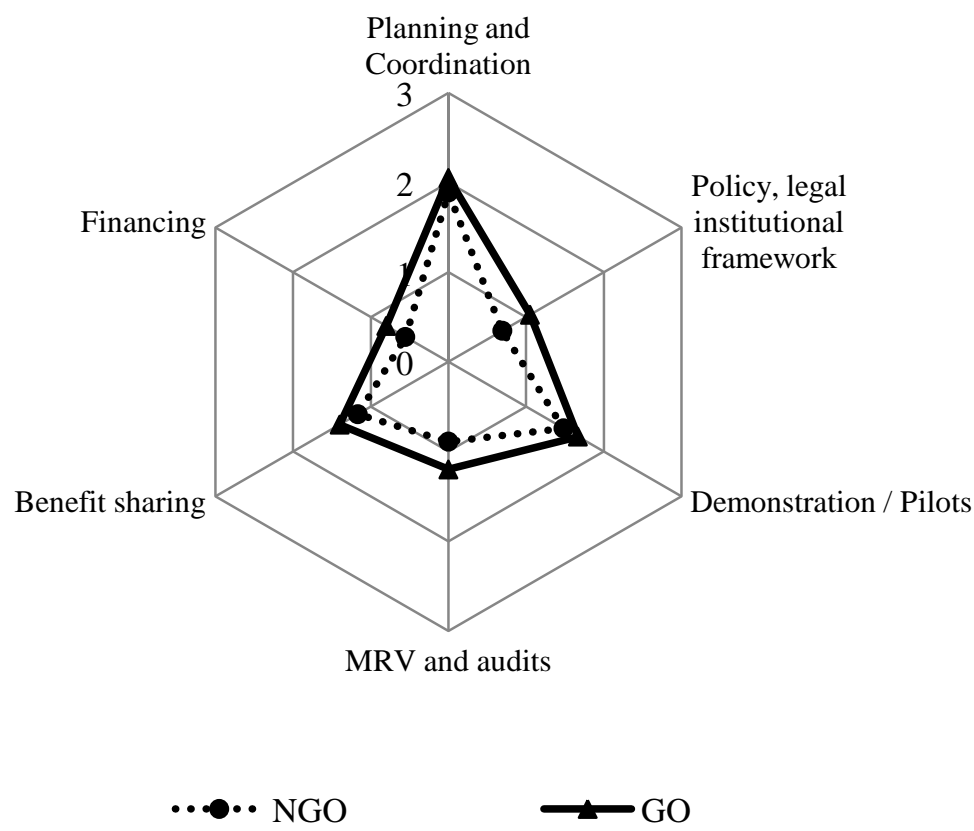

Figure 6. GO and NGO assessment of REDD+ readiness

The marked difference between NGO and GO assessment on SIS, tenure and carbon rights, MRV responsibilities, and conflict resolution framework corroborate with other authors, among others, Sunderlin \& Huynh (2005), Peskett \& Brockhaus (2009) and Pham et al., (2012). These authors mentioned that differences exist in State and non-State actors' perceptions over forest tenure particularly when it relates to indigenous peoples.

The NGO group also expressed concerns about the ambiguity of Vietnam's legal tenure system particularly around forest, land ownership and carbon rights, with respect to the requirements of REDD+; in contrast, the GO group was confident on the recourse and dispute settlement mechanism that the government is using when dealing with REDD+ related complaints. Both groups however, admitted that carbon rights and contractual arrangements were discussed only recently.

Perhaps due to its leadership in these issues within the NRN, SIS and nesting rules were rated highly by the NGO group. Notably, the STWG for safeguards is headed by an NGO, and Forest Trends, for example, has organized a national workshop on integrating national and sub-national approaches to REDD+ in Vietnam (To et al., 2012b) which is the only effort concerning REDD+ nesting in the country.

\section{Discussion}

From the foregoing analyses, it is clear that despite the acclaimed efforts in reforestation and significant support of the UN-REDD Programme, the World Bank's FCPF and other international 
NGOs, myriad issues remain, more work is needed before Vietnam can be fully ready for a national REDD+ implementation.

\subsection{REDD+ readiness and drivers of deforestation and degradation}

The fact that tropical deforestation is driven mainly by economic factors, institutions, national policies and remote influences have not been given high importance in analyzing how countries can reverse deforestation and degradation (Skutsch \& McCall, 2010; Corbera, Estrada \& Brown, 2010). Like many other countries, Vietnam does not have a specific strategy that directly addresses deforestation and degradation (Brown \& Bird, 2008; Corbera \& Schroeder, 2010; Hall, 2011). Even the NRAP does not include activities that address drivers of deforestation and degradation, as suggested by the UNFCCC, the World Bank, and some authors like Eliasch (2008).

Furthermore, no REDD+ policies have been formulated to address drivers of deforestation and degradation outside the forest sector, or to reconcile conflicts between forest conservation and economic development. The absence of underlying drivers of deforestation in the REDD+ debate in Vietnam indicates that current interests are detached from the core objectives of REDD+ (Angelsen et al., 2009). A good example is the targeted 150,000 has of new rubber plantation within poor natural forest areas by $2020^{\text {(ii) }}$. With incoherent agricultural, economic and environmental policies, this target has been pushed with undue consideration of REDD+ efforts by sectors that have no interest on REDD+. Criticisms have been passed around Vietnam that as long as large-scale forest conversion continues, and the drivers of degradation and deforestation are not addressed, the country will only be superficially ready for REDD+. The fair rating given to REDD+ Strategy, R-PIN and PDD can thus be interpreted only as recognition of the existence of such policy documents than being ready for REDD+. Optimistically, the existence of the NRAP and other policy documents signaled a strong political commitment of Vietnam to REDD+, and the Prime Minister's imprimatur ensured national sovereignty over the REDD+ process.

\subsection{Institutional structure for REDD+}

Behind the REDD+ institutional structure are concerns about clarity of roles, and efficiency and effectiveness of such structure. The ambiguous roles of the Ministry of Natural Resources and Environment (MONRE), the Committee of Ethnic Minority Affairs (CEMA), and VNFOREST's affiliated units, as well as the complacent attitudes of Ministry staff that lack interest on REDD+ (UNREDD, 2012) is a tall order for the understaffed VRO. This needs urgent action if these agencies are to be involved in REDD+.

Many opportunities were also wasted with the slow uptake of STWG outputs. Pham et al., (2012) mentioned that this is due to fewer government staff who were dedicated to the NRN and the constricted decision-making channel, both of which points to the need for revamping current GO representation in the NRN, and devolving some decisions to the VRO and MARD.

The lack of indigenous people's participation in the NRN composition could be due to the fact that local people in protected areas often, ethnic minorities have always been viewed as the problem, rather than the solution by the Vietnamese Government and some conservationists (Boissière, Sheil,

\footnotetext{
(ii) Decision 750/QD-TTg of the Prime Minister issued in 2007
} 
Basuki, Wan \& Le, 2009). Ethnic minorities are given preferential treatments when it comes to social services, but not in decision-making. Current REDD+ readiness efforts have not shown improvements in this regard, although some consultations have been already conducted in Lam Dong and Bac Kan provinces. But guidance on how local people can participate in REDD+ has not yet been considered, while developing a recourse mechanism (i.e. REDD+ conflicts resolution framework) was only mentioned in few documents. The low rating for this indicator [lowest amongst indicators (0.29)] is thus well founded.

The contribution of REDD+ readiness activities to securing rights to use and manage forests that is proven more effective than State management in many cases (Nagendra, 2007; Blomley et al., 2008; Somanathan, Prabhakar \& Mehta, 2009) also remains doubtful. To, Dressler, Mahanty, Pham, \& Zingerli (2012a) found that centralized state forest land management in Lam Dong province constrained local households from receiving PFES benefits, and triggered conflict in villages, and that strong state protection might lead to structural problems. There have been a number of proposals for institutional and policy reforms toward decentralized forest management, but the government may have been acting on these proposals complacently. These findings imply a real challenge to REDD+ in Vietnam. Without forest governance regime that encourages active participation from local communities, REDD+ will likely repeat the mistakes of past reforestation projects that have done little to stimulate individual initiative and participation (Castella et al., 2005), which could undermine the core objectives of REDD+. The above raises question as to whether local peoples' participation, among others, can even be an indicator for REDD+ readiness for a country like Vietnam where 'participatory governance' is still a distant vision. The idea of tailor-made REDD+ indicators to suit a country's political context has been floated, and could be an interest for research in Vietnam, as other authors have done in other countries, but this requires the global REDD Programme to be flexible enough to adopt both general and specific indicators for REDD+.

The low participation of the private sector is a result of mixed causes. First, the Vietnamese Government prefers a fund-based approach to REDD+, which fits the realities of centralized land ownership and potentially reduces opportunities for the private sector (Burgess et al., 2010). Second, is the great uncertainty of REDD+ at international and national levels, the centralized governance structure, and the lack of clear mechanism to enforce environmental and social safeguards that are considered critical determinants of private sector involvement in REDD+ (Lin \& Streck, 2011; Bernard, McFatridge \& Minang, 2012). Nonetheless, while a radical reform toward decentralization and market-orientation could not be expected to happen in the near future, private sector paritcipation could be promoted through REDD+ safeguards, where links with market regulations such as FLEGT is of interest. In sum, the existing institutional structure for REDD+ in Vietnam may be more efficient than fair.

\subsection{Tenure, carbon rights and benefit sharing}

The situation in Vietnam is not unique when it comes to tenure. Many countries preparing for REDD+ face similar issues due to ambiguity of legal framework on natural resources and property rights, on which the definition of carbon rights depends (Suzuki, 2011). Very few countries have developed laws on carbon (Skutsch, 2010). As mentioned before, carbon rights, contractual arrangements and REDD+ conflict resolution were discussed only recently. Although, BDS principles and guidelines have been identified, discussions on recourse mechanism for REDD+ benefit distribution as 
recommended by UN-REDD have not prospered. Williams \& David (2011) also found that the R-PP of Vietnam does not provide any information on types of disputes and how they were resolved.

Undoubtedly, tenure and carbon rights/contractual arrangement and conflict resolution are crucial to the future of REDD+. With unclear and overlapping forest land rights in Vietnam (UN-REDD, 2010; To et al., 2012b), carbon rights may complicate the implementation of REDD+ due to great variation in forest use between different forest groups. Tenure and carbon rights relates to all functions, and can thus, be a bottleneck to REDD+ implementation as mentioned earlier; however carbon rights can be resolved through reforms in pertinent legal frameworks such as the Land Law (2003), Law on Environmental Protection (2005) and Law on Forest Protection and Development (2004); otherwise, a well-designed contractual arrangement could be an option, with some legislative modifications.

Policy discussions around carbon rights and contractual arrangement should involve as many actors as possible that will directly or indirectly benefit from the REDD+ Programme. This is important for Vietnam, where the risks of retaining REDD+ financial benefit by the government or new risks to be introduced are real (Peskett \& Brockhaus, 2009; Angelsen, Brockhaus, Sunderlin, \& Verchot, 2012). The development of a REDD+ conflict resolution framework and national registry also need to be initiated urgently.

Building upon earlier forest conservation programs including the most recent PFES Programme, REDD+ benefit sharing in Vietnam can be seen as fairly advanced compared to other REDD+ readiness domains and indicators. As mentioned earlier, a REDD+ Fund has been established as part of the FPDF, which has been used since 2008 to distribute PFES benefits. However, some institutional aspects of PFES will have to be employed with a caveat that the management of REDD+ revenues requires some degree of legal certainty (UN-REDD, 2010).

Pham et al. (2013) reviewed REDD+ benefit sharing approaches in 13 countries and found that most countries are trying to establish new institutional arrangements for REDD+ operations while Vietnam and Brazil aim to use existing institutional mechanisms. Reducing operational cost has been the reason for making use of existing institutional structures. The economic and political rationale of this approach is clear since the State has retained its role despite the shift toward free and market-oriented schemes (To et al., 2012a; McElwee, 2012).

Moreover, a performance based scheme like REDD+ is as difficult as an input-based PES mechanism. A flat rate payment per hectare to all participants that comply with management agreements can be the most convenient approach to reduce emissions from deforestation (Torres \& Skutsch, 2012). A performance-based approach however, which is more relevant to Vietnam's forest transition, requires higher technical and institutional capacity, and is currently a gap.

\subsection{MRV and Audit and Nesting}

The weakness of forest monitoring, information and reporting in Vietnam is recognized within and outside the forestry sector (Lang, 2001; Hoang et al., 2010; UN-REDD, 2011b; SRV, 2011), characterized by lack of coordination, irregular data collection and sharing, and poor technological infrastructure. Confusion about the roles of the VRO and the Designated National Authority (DNA) for CDM under MONRE on emission reduction registration was also revealed. Hence, it was unsurprising that this indicator was rated the least in the MRV function. 
It has to be noted that while Vietnam's UN-REDD Programme puts heavy emphasis on setting up MRV protocols, the development of a national baseline/reference level has mainly been carried out by JICA. A report on 'interim' RELs and baseline development was released by JICA in March 2012 (JOFCA \& JAFTA, 2012). The FORMIS project of the Government of Finland is also helping Vietnam improve its national forest inventory database. With ample external support, the technical issues of national REDD+ MRV would have been all addressed. The respondents were however, unsure about how and whether the data, methodologies and recommendations from these projects will be adopted by the government. Nonetheless, the draft MRV framework indicated that all seven areas of safeguards would be included in the global information system; however respondents further commented that it might take longer to put the Safeguards Information System (SIS) in place.

Linking national and subnational REDD+ projects is also real challenge in Vietnam. The projectbased approach is still dominant and no legal framework exists with which to base the nesting of subnational initiatives into the NRAP. Such legal framework needs to include aspects of carbon rights, national accounting, MRV and benefit sharing, among others. Studies about cross-scale benefit sharing such as those conducted by Hoang et al., (2013) and the efforts of SNV and VNFOREST to create an 'interim' REDD+ registration system needs to be effectively communicated to obtain 'buyin' from the NRN and VRO. However, nesting rules appears to be less urgent for almost all respondents possibly due to the fact most REDD+ projects in Vietnam are still focusing on capacity building than carbon offsets per se--- these projects are all waiting to be endorsed for inclusion into the NRP operations, and thereafter transform into a fund-based model. A national registration agency for emission reduction or REDD+ was to be established; however this was not also urgent for most respondents.

\subsection{Reforestation and REDD+}

Forest plantations, either by State forest enterprises (SFEs) or individual households have been key to restoring Vietnam's forest cover (The \& Ngoc, 2008, Sandewall et al., 2010). By 2010, the contribution of planted forest to the total forest area of Vietnam was 22\% (MARD's statistics, 2011) while the global rate was only 7\% (FAO, 2010). Since most of these plantations were established in deforested areas, it may (and should) generate carbon credits under REDD+ if an appropriate accounting method is applied (Dyer, Matthews, \& Meyfroidt, 2012). However, whether these activities are going to be institutionally included under the "+" in REDD+ remains a question. The argument is that Vietnam should not be penalized, and should instead, be rewarded for its reforestation efforts under a REDD+ scheme. Nevertheless, as afforestation, avoided deforestation and forest management are not independent (Bosetti \& Rose, 2011), it implies that more balanced policies than a focus on replanting only is desirable for REDD+ planning and design in Vietnam.

\section{Will past reforestation create enough momentum for REDD+ readiness?}

Reflecting on past reforestation projects, particularly Programme 661 where the Vietnamese government mobilized internal funding and human resources for a goal similar to REDD+, with difference only in the latter's emphasis on emission reductions and performance-based monitoring and incentives, the question then arise, is Vietnam ready for REDD+? Certainly, the donor community has high expectations on Vietnam's readiness for REDD+ implementation--the government's experience in mobilizing internal resources and homegrown strategies during its 20 years of reforestation was expected to mirror REDD+ readiness. But, as this assessment suggests, the rules and 
requirements imposed by the global REDD mechanism are a tall order for Vietnam - the same rules and requirements on reforestation that are used to define the country's readiness for REDD + , are baffling national and local REDD+ efforts. Strict adherence to REDD+ rules and requirements therefore means that Vietnam's vast experience in reforestation does not make it sufficiently ready for REDD+ implementation. However, the government's response to REDD+ is noteworthy---it is progressively responding to new demands, issues and opportunities. From a project management perspective, Vietnam's readiness may well be achieved within a REDD+ project cycle.

\section{Conclusion}

In conclusion, Vietnam is only partially ready for REDD + with 'fair' as the highest rating for some functions and low for several undeveloped indicators. Specifically, it scored fairly in Planning and Coordination, Demonstration/pilots, Benefit-sharing and MRV, owing to the development of the REDD-RPIN and RPP, the National REDD+ Strategy, BDS principles, MRV framework, as well as, relevant policies predating REDD+. Despite the poor rating of Vietnam's Policy, Legal and Institutional Framework, the creation of REDD+ implementing structure, with all its imperfections, can however, be seen as a leap of faith of the Vietnamese government and a significant step towards achieving readiness, albeit this should not mask inherent structural flaws, and undermine many unresolved post-reforestation issues that underlie forest degradation and deforestation.

For the country to move beyond its current state of REDD+ readiness, future activities should focus on indicators where it is weak while strengthening those that are already advancing. Failure to strengthen the weak indicators will mean an uphill implementation of the NRAP. The following actions are recommended: (i) shift from too much focus on replanting policies to a more balanced policy approach so that local people can access a wide array of benefits not only from REDD+ but also other relevant programmes; (ii) refine the NRAP and amend relevant forest policies to reverse drivers of deforestation and degradation; (iii) remove policy and institutional bottlenecks through reforms in the forest and land laws, as well as jurisdictional process, to address tenure and carbon rights, equitable benefit sharing, and conflict resolution, and (iv) enhance inter-agency collaboration and broaden sectoral participation, to include private sector and indigenous peoples' representation in the NRSC, to increase the legitimacy and effectiveness of REDD+ readiness. Despite the limited number of participants to this in depth-case study, it generated useful information and recommendations that are not only useful to Vietnam but also to other developing countries that share similar issues with Vietnam. 


\section{References}

Angelsen, A., Brockhaus, M., Kanninen, M., Sills, E., Sunderlin, W. D., \& Wertz-Kanounnikoff, S. (Eds.) (2009). Realising REDD+: National strategy and policy options. Bogor: Centre for International Forestry Research (CIFOR)

Angelsen, A., Brockhaus, M., Sunderlin, W.D., \& Verchot, L.V. (Eds). (2012) Analysing REDD+: Challenges and choices. Bogor: Centre for International Forestry Research (CIFOR)

Atmadja, S., \& Verchot, L. (2011). A review of the state of research, policies and strategies in addressing leakage from reducing emissions from deforestation and forest degradation (REDD+). Mitig Adapt Strateg Glob Change (2012) 17:311-336

Bernand, F., McFatridge, S., \& Minang, P.A. (2012). The Private Sector in the REDD+ Supply Chain: Trends, challenges and opportunities. IISD report August 2012. Manitoba: International Institute for Sustainable Development

Blomley, T., Pfliegner, K., Isango, J., Zahabu, E., Ahrends, A., \& Burgess, N. (2008). Seeing the wood for the trees: An assessment of the impact of participatory forest management on forest condition in Tanzania. Oryx, 42(3), 380-391 doi:http://dx.doi.org/10.1017/S0030605308071433

Bosetti, V., \& Rose, S. K. (2011). Reducing carbon emissions from deforestation and forest degradation: Issues for policy design and implementation. Environment and Development Economics, 16(4), 357-360 doi:http://dx.doi.org/10.1017/S1355770X11000143

Boissière, M., Sheil, D., Basuki, I., Wan, M., \& Le, H. (2009). Can engaging local people's interests reduce forest degradation in central Vietnam? Biodiversity \& Conservation, 18(10), 2743-2757. doi:http://dx.doi.org/10.1007/s10531-009-9627-1

Boykoff, T. M., \& Boykoff, M. J. (2007). Climate change and journalistic norms: a case-study of US massmedia coverage. Geoforum, 38, 1190-1204. doi:10.1016/j.geoforum.2007.01.008

Brown, D., \& Bird, N., (2008). The REDD Road to Copenhagen: Readiness for What? Opinion 118. London: Overseas Development Institute

Burgess, N. D., Bahane, B., Clairs, T., Danielsen, F., Dalsgaard, S., Funder, M., . . Zahabu, E. (2010). Getting ready for REDD+ in Tanzania: A case study of progress and challenges. Oryx, 44(3), 339-351. doi:http://dx.doi.org/10.1017/S0030605310000554

Castella, J.-C., V. Gevraise, \& P. Novosad. (2005). Centralized planning and economic reforms in a mountainous region of Vietnam. Journal of Contemporary Asia 5:166-182.

Collins, N. M., Jeffrey A. Sr, \& Timothy C. W. (1991). The Conservation Atlas of Tropical Forests: Asia and the Pacific. New York, NY: Simon \& Schuster

Corbera, E., Estrada, M., \& Brown, K. (2010). Reducing greenhouse gas emissions from deforestation and forest degradation in developing countries: Revisiting the assumptions. Climatic Change, 100(3-4), 355-388 doi:http://dx.doi.org/10.1007/s10584-009-9773-1

Corbera, E., \& Schroeder, H. (2011). Governing and implementing REDD+. Environmental Science \& Policy 14 (2011) 89-99. doi:10.1016/j.envsci.2010.11.002

De Jong, W., Do, D. S., \& Trieu, V. H. (2006). Forest rehabilitation in Vietnam: History, reality and future. Bogor: Centre for International Forestry Research (CIFOR).

De Koninck, R. (1999). Deforestation in Vietnam. Ottawa : International Development Research Centre (IIED)

Dyer, G. A., Matthews, R., \& Meyfroidt, P. (2012). Is there an ideal REDD+ program? an analysis of policy trade-offs at the local level. PLoS One, 7(12) doi:http://dx.doi.org/10.1371/journal.pone.0052478 
Dinh, H. H., \& Dang, K. S. (2008). Land and forest allocation in Viet Nam - Policy and implementation. Hanoi: Institute for Policies and Strategies in Agriculture and Rural Development (IPSARD)

Eliasch, J. (2008). Climate Change: Financing Global Forests. London: HMSO. Retrieved from: http://www.official-documents.gov.uk/document/other/9780108507632/9780108507632.pdf

Food and Agriculture Organization of the United Nations (FAO). (2010). Global Forest Resources Assessment 2010. FAO Forestry Paper 163. Rome: FAO. Retrieved from: http://www.fao.org/docrep/013/i1757e/i1757e00.htm

Hall, A. (2011). GETTING REDD-Y: Conservation and climate change in Latin America. Latin American Research Review, 46, 184-210, 214-215. Retrieved from http://search.proquest.com/docview/1368622143?accountid=34304

Hoang, M. H., Do, T. H., van Noordwijk, M., Pham, T.T., Palm, M., To, X. P., ..Hoang, T.V.A. (2010). An assessment of opportunities for reducing emissions from all land uses - Vietnam preparing for REDD. Final National Report. Nairobi: ASB Partnership for the Tropical Forest Margins.

Hoang, M. H., Do, T. H., Pham, M.T., van Noordwijk, M., \& Minang, P. A. (2013). Benefit distribution across scales to reduce emissions from deforestation and forest degradation (REDD+) in Vietnam. Land Use Policy, 31, 48-60. doi:10.1016/j.landusepol.2011.09.013

International Sustainability Unit (ISU). 2012. Interim REDD+ Finance: Current Status and Ways Forward for 2013-2020. 31p. Retrieved from: http://www.pcfisu.org/wpcontent/uploads/2012/11/Nov-2012-Interim-REDD+-Finance-Current-Status-and-Ways-Forward2013-2020-Princes-Rainforests-Project.pdf

Japan Overseas Forestry Consultants Association (JOFCA) \& Japan Forest Technology Association (JFTA). (2012). The Study on Potential Forests and Land Related to "Climate Change and Forests" in the Socialist Republic of Vietnam. Final report. Hanoi: JICA.

Johns, T., Johnson, E., \& Greenglass, N. 2009. An Overview of Readiness for REDD: A compilation of readiness activities prepared on behalf of the Forum on Readiness for REDD. Falmouth, MA: The Woods Hole Research Center. Retrieved from: http://www.cbd.int/forest/doc/overviewreadiness-redd.pdf

Lambin, E. F., \& Meyfroidt, P. (2010). Land use transitions: Socio-ecological feedback versus socioeconomic change. Land Use Policy, 27, 108-118. doi: 10.1016/j.landusepol.2009.09.003

Lang, C. (2001). Deforestation in Vietnam, Laos and Cambodia, in D.K. Vajpeyi (Ed.) Deforestation, Environment, and Sustainable Development: A Comparative Analysis. Westport, Connecticut and London: Praeger. pp. 111-137.

Lin, J., \& Streck, C. (2009). Mobilising finance for climate change mitigation: private sector involvement in international carbon finance mechanisms. Melbourne Journal of International Law, 10(1), 70-101. Retrieved from http://search.proquest.com/docview/217506006?accountid=34304

Mattsson, E., Persson, U.M., Ostwald, M., \& Nissanka, S.P. (2012). REDD+ readiness implications for Sri Lanka in terms of reducing deforestation. Journal of Environmental Management 100 (2012) 29-40. doi:10.1016/j.jenvman.2012.01.018

Mayers, J., Maginnis, S., \& Arthur, E. (2010). REDD Readiness Requires Radical Reform: Prospects for Making the Big Changes Needed to Prepare for REDD-plus in Ghana: Co-chairs' Summary of an International REDD Readiness Dialogue in Ghana, June 2010. New Haven, CT: The Forests Dialogue. Retrieved from: http://www.growingforestpartnerships.org/sites/growingforestpartnerships.org/files/gfp_REDDRea diness_Ghana_Report.pdf 
McElwee, P. (2012). Payments for environmental services as neoliberal market-based forest conservation in Vietnam: panacea or problem? Geoforum 43 (3) 412-426.

doi:10.1016/j.geoforum.2011.04.010

Mertz, O., Muller, D., Sikor, D., Hett, C., Andreas-Heinimann, Castell, J.C.,... Sun, Z. (2012). The forgotten D: challenges of addressing forest degradation in complex mosaic landscapes under REDD. Geografisk Tidsskrift-Danish Journal of Geography, 112 (1), 63-76. doi:10.1080/00167223.2012.709678

Meyfroidt , P., \& Lambin, E. F. (2008). The causes of the reforestation in Vietnam. Land Use Policy, 25 (182-197). doi: 10.1016/j.landusepol.2007.06.001

Meyfroidt, P., \& Lambin, E. F. (2009). Forest transition in Vietnam and displacement of deforestation abroad. Proceedings of the National Academy of Sciences 106 (38), 16139-16144

Meyfroidt, P., \& Lambin, E.F. (2011). Global Forest Transition: Prospects for an End to Deforestation. Annu. Rev. Environ. Resour, 36, 343-371. doi: 10.1146/annurev-environ-090710143732

Minang, P. A., van Noordwijk, M., Duguma, L. A., Kahurani, E., Do, T. H., Bernard, F., ..... Widayati, A. (submitted 2013). REDD+ Readiness footprints across the tropics: time for a rethink (This issue)

Ministry of Agriculture and Rural Development of Vietnam (MARD). (2011). Quyết định số 1828/QĐ-BNN-TCLN ngày 11/8/2011 về việc công bố hiện trạng rừng toàn quốc năm 2010 [Decision No. 1828/QD-BNN/TCLN dated of 11 August 2011 to announce Vietnam's forest status in 2010]. Retrieved from http://www.kiemlam.org.vn/Desktop.aspx/Tainguyen/Quyetdinh/907D0382AAA44BDBAD7101C74E9B110C (January 2013)

Nagendra, H. (2007). Drivers of reforestation in human-dominated forests. Proceedings of the National Academy of Sciences of the USA, 104, 15218-15223

Parker, C. (2011). Getting ready for REDD: The REDD Countries database of the REDD Desk. Presentation by Charlie Parker, Head of Policy, Global Canopy Programme at Oxford Centre for Tropical Forests. March 4, 2011. Retrieved from: http://www.theredddesk.org/es/node/3166

Pham, T. T. (2011). REDD+ politics in the media: a case study from Vietnam. Working Paper 53. Bogor: Centre for International Forestry Research (CIFOR)

Pham,T.T., Moeliono, M., Nguyen,T.H., Nguyen, H.T., \& Vu, T.H. (2012). The context of REDD+ in Vietnam:Drivers, agents and institutions. Occasional Paper 75. Bogor: Bogor: Center for International Forestry Research (CIFOR)

Pham, T.T., Brockhaus, M., Wong, G., Dung, L.N., Tjajadi, J.S., Loft, L., Luttrell C. \& Assembe Mvondo, S. (2013). Approaches to benefit sharing: A preliminary comparative analysis of 13 REDD+ countries. Working Paper 108. CIFOR, Bogor, Indonesia

Peskett, L., \& Brockhaus, M. (2009). When REDD+ goes national: A review of realities, opportunities and challenges. In Angelsen, A., Brockhaus, M., Kanninen, M., Sills, E., Sunderlin, W. D., \& Wertz-Kanounnikoff, S. (Eds.) (2009). Realising REDD+: National strategy and policy options. Bogor: Center for International Forestry Research (CIFOR)

Rambaldi, G., Bugna, S., \& Geiger, M. (2001). Review of the protected area system of Vietnam. Special Report. Asean Biodiversity, pp 43-51

Sandewall, M., Ohlsson, B., Sandewall, R. K., \& Viet, L. S. (2010). The expansion of farm-based plantation forestry in vietnam. Ambio, 39 (8), 567-79. Retrieved from http://search.proquest.com/docview/856980400?accountid=34304

Scheyvens, H. (Eds). (2010). Developing National REDD-plus Systems: Progress challenges and ways forward - Indonesia and Viet Nam country studies. Hayama: Institute for Global Environmental Strategies 
Scheyvens, H., Hyakumura, K., \& Seki, Y. (Eds). (2007). Decentralisation and State-Sponsored Community Forestry in Asia. Hayama: Institute for Global Environmental Strategies. Retrieved from: http://enviroscope.iges.or.jp/modules/envirolib/view.php?docid=809

Simula M. (2010). Analysis of REDD+ Financing Gaps and Overlaps (Ardot, 30 December 2010; prepared on commission by the REDD+ Partnership). Retrieved from http://reddpluspartnership.org/25159-09eb378a8444ec149e8ab32e2f5671b11.pdf (November 2012)

Skutsch, M. M., \& Mccall, M. K. (2010). Reassessing REDD: Governance, markets and the hype cycle. Climatic Change, 100(3-4), 395-402 doi:http://dx.doi.org/10.1007/s10584-009-9768-y

Skutsch, M. (2013). Slicing the REDD+ pie: controversies around the distribution of benefits. CAB Reviews, 2013, 8, 020, 1-10

Socialist Republic of Vietnam (SRV). (2008). Readiness plan ideas note (RPIN). Washington, DC: Forest Carbon Partnership Facility. Retreive from http://www.forestcarbonpartnership.org/fcp/VN

Socialist Republic of Vietnam (SRV). (2011). Readiness Preparation Proposal (R-PP). Forest Carbon Partnership Facility. Retrieved from http://vietnam-redd.org/Upload/Download/File/Viet_Nam_RPP_Revised_November_2011_4536.pdf

Somanathan, E., Prabhakar, R., \& Mehta, B.S. (2009). Decentralization for cost-effective conservation. Proceedings of the National Academy of Sciences of the USA, 106, 4143-4147

Sunderlin, W. D., \& Huynh, T. B. (2005). Poverty Alleviation and Forests in Vietnam. Bogor: Center for International Forestry Research (CIFOR)

Suzuki, R. (2011). Carbon Rights and REDD+. REDD-Net Bulletin, Asia-Pacific, Issue 03, January 2011. Retrieved from http://redd-net.org/resource-library/redd-net-asia-pacific-bulletin-3-carbonrights-and-redd

The, B. D., \& Ngoc, H. B. (2008). Payments for environmental services in vietnam: An empirical experiment in sustainable forest management. ASEAN Economic Bulletin, 25(1), 48-59. Retrieved from http://search.proquest.com/docview/219626485? accountid=34304

To, P. X., Dressler, W. H., Mahanty, S., Pham, T. T., \& Zingerli, C. (2012a). The prospects for payment for ecosystem services (PES) in vietnam: A look at three payment schemes. Human Ecology, 40(2), 237-249. doi:http://dx.doi.org/10.1007/s10745-012-9480-9

To, X.P., O’Sullivan, R., Olander, J., Hawkins, S., Pham, Q.H., \& Kitamura, N. (2012b). REDD+ in Vietnam: Integrating National and Subnational Approaches. Forest Trends Association and Climate Focus. 35 p. Retrieved from: http://www.foresttrends.org/publication_details.php?publication ID $=3227$

Torres, A.B., \& Skutsch, M. (2012). Splitting the Difference: A Proposal for Benefit Sharing in Reduced Emissions from Deforestation and Forest Degradation (REDD+). Forests 2012, 3, 137 154; doi:10.3390/f3010137

UN-REDD Programme (UN-REDD). (2010). Design of a REDD-Compliant Benefit Distribution System for Vietnam. Hanoi: UN-REDD Programme

UN-REDD Programme (UN-REDD). (2011a). Analysis of Opportunity Cost for REDD+. Hanoi: UNREDD Programme

UN-REDD Programme (UN-REDD). (2011b). Measurement, Reporting and Verification (MRV) Framework Document. Hanoi: UN-REDD Programme

UN-REDD Programme (UN-REDD) \& Forest Carbon Partnership Facility (FCPF). (2012). Country Needs Assessment: a report on REDD+ Readiness among UN-REDD Programme and FCPF Member Countries. Retrieved from www.forestcarbonpartnership.org (November 2012)

UN-REDD Programme (UN-REDD). (2012). Lessons Learned Viet Nam UN-REDD Programme, Phase 1. Hanoi: UN-REDD Programme 
Wertz-Kanounnikoff, S., \& Kongphan-Apirak, M. (2009). Emerging REDD+: A preliminary survey of demonstration and readiness activities. Working Paper 46. CIFOR, Bogor, Indonesia

Westholm. (2010). Getting Ready for REDD+. FOCALI Report, 2010: 01. Gothenburg: FOCALI. Retrieved from http://www.fao.org/fileadmin/user_upload/rome2007/docs/Getting\%20ready\%20for\%20REDD+.p df (November 2012)

Williams, L.G., \& Davis, C. (2011). Getting Ready with Forest Governance: A Review of the Forest Carbon Partnerhip Facility Readiness Preparation Proposals and the UN-REDD National Programme Documents., v 1.8. WRI Working Paper. Washington, DC: World Resources Institute. Retrieved from http://www.wri.org/publication/getting-ready 



\section{WORKING PAPERS IN THIS SERIES}

2005

1. Agroforestry in the drylands of eastern Africa: a call to action

2. Biodiversity conservation through agroforestry: managing tree species diversity within a network of community-based, nongovernmental, governmental and research organizations in western Kenya.

3. Invasion of prosopis juliflora and local livelihoods: Case study from the Lake Baringo area of Kenya

4. Leadership for change in farmers organizations: Training report: Ridar Hotel, Kampala, 29th March to 2nd April 2005.

5. Domestication des espèces agroforestières au Sahel : situation actuelle et perspectives

6. Relevé des données de biodiversité ligneuse: Manuel du projet biodiversité des parcs agroforestiers au Sahel

7. Improved land management in the Lake Victoria Basin: TransVic Project's draft report.

8. Livelihood capital, strategies and outcomes in the Taita hills of Kenya

9. Les espèces ligneuses et leurs usages: Les préférences des paysans dans le Cercle de Ségou, au Mali

10. La biodiversité des espèces ligneuses: Diversité arborée et unités de gestion du terroir dans le Cercle de Ségou, au Mali

\section{6}

11. Bird diversity and land use on the slopes of Mt. Kilimanjaro and the adjacent plains, Tanzania

12. Water, women and local social organization in the Western Kenya Highlands

13. Highlights of ongoing research of the World Agroforestry Centre in Indonesia

14. Prospects of adoption of tree-based systems in a rural landscape and its likely impacts on carbon stocks and farmers' welfare: The FALLOW Model Application in Muara Sungkai, Lampung, Sumatra, in a 'Clean Development Mechanism' context

15. Equipping integrated natural resource managers for healthy Agroforestry landscapes.

17. Agro-biodiversity and CGIAR tree and forest science: approaches and examples from Sumatra.

18. Improving land management in eastern and southern Africa: A review of policies.

19. Farm and household economic study of Kecamatan Nanggung, Kabupaten Bogor, Indonesia: A socioeconomic base line study of Agroforestry innovations and livelihood enhancement.

20. Lessons from eastern Africa's unsustainable charcoal business.

21. Evolution of RELMA's approaches to land management: Lessons from two decades of research and development in eastern and southern Africa

22. Participatory watershed management: Lessons from RELMA's work with farmers in eastern Africa.

23. Strengthening farmers' organizations: The experience of RELMA and ULAMP.

24. Promoting rainwater harvesting in eastern and southern Africa.

25. The role of livestock in integrated land management.

26. Status of carbon sequestration projects in Africa: Potential benefits and challenges to scaling up.

27. Social and Environmental Trade-Offs in Tree Species Selection: A Methodology for Identifying Niche Incompatibilities in Agroforestry [Appears as AHI Working Paper no. 9]

28. Managing tradeoffs in agroforestry: From conflict to collaboration in natural resource management. [Appears as AHI Working Paper no. 10]

29. Essai d'analyse de la prise en compte des systemes agroforestiers pa les legislations forestieres au Sahel: Cas du Burkina Faso, du Mali, du Niger et du Senegal.

30. Etat de la recherche agroforestière au Rwanda etude bibliographique, période 1987-2003

2007

31. Science and technological innovations for improving soil fertility and management in Africa: A report for NEPAD's Science and Technology Forum.

32. Compensation and rewards for environmental services. 
33. Latin American regional workshop report compensation.

34. Asia regional workshop on compensation ecosystem services.

35. Report of African regional workshop on compensation ecosystem services.

36. Exploring the inter-linkages among and between compensation and rewards for ecosystem services CRES and human well-being

37. Criteria and indicators for environmental service compensation and reward mechanisms: realistic, voluntary, conditional and pro-poor

38. The conditions for effective mechanisms of compensation and rewards for environmental services.

39. Organization and governance for fostering Pro-Poor Compensation for Environmental Services.

40. How important are different types of compensation and reward mechanisms shaping poverty and ecosystem services across Africa, Asia \& Latin America over the Next two decades?

41. Risk mitigation in contract farming: The case of poultry, cotton, woodfuel and cereals in East Africa.

42. The RELMA savings and credit experiences: Sowing the seed of sustainability

43. Yatich J., Policy and institutional context for NRM in Kenya: Challenges and opportunities for Landcare.

44. Nina-Nina Adoung Nasional di So! Field test of rapid land tenure assessment (RATA) in the Batang Toru Watershed, North Sumatera.

45. Is Hutan Tanaman Rakyat a new paradigm in community based tree planting in Indonesia?

46. Socio-Economic aspects of brackish water aquaculture (Tambak) production in Nanggroe Aceh Darrusalam.

47. Farmer livelihoods in the humid forest and moist savannah zones of Cameroon.

48. Domestication, genre et vulnérabilité : Participation des femmes, des Jeunes et des catégories les plus pauvres à la domestication des arbres agroforestiers au Cameroun.

49. Land tenure and management in the districts around Mt Elgon: An assessment presented to the Mt Elgon ecosystem conservation programme.

50. The production and marketing of leaf meal from fodder shrubs in Tanga, Tanzania: A pro-poor enterprise for improving livestock productivity.

51. Buyers Perspective on Environmental Services (ES) and Commoditization as an approach to liberate ES markets in the Philippines.

52. Towards Towards community-driven conservation in southwest China: Reconciling state and local perceptions.

53. Biofuels in China: An Analysis of the Opportunities and Challenges of Jatropha curcas in Southwest China.

54. Jatropha curcas biodiesel production in Kenya: Economics and potential value chain development for smallholder farmers

55. Livelihoods and Forest Resources in Aceh and Nias for a Sustainable Forest Resource Management and Economic Progress

56. Agroforestry on the interface of Orangutan Conservation and Sustainable Livelihoods in Batang Toru, North Sumatra.

\section{8}

57. Assessing Hydrological Situation of Kapuas Hulu Basin, Kapuas Hulu Regency, West Kalimantan.

58. Assessing the Hydrological Situation of Talau Watershed, Belu Regency, East Nusa Tenggara.

59. Kajian Kondisi Hidrologis DAS Talau, Kabupaten Belu, Nusa Tenggara Timur.

60. Kajian Kondisi Hidrologis DAS Kapuas Hulu, Kabupaten Kapuas Hulu, Kalimantan Barat.

61. Lessons learned from community capacity building activities to support agroforest as sustainable economic alternatives in Batang Toru orang utan habitat conservation program (Martini, Endri et al.)

62. Mainstreaming Climate Change in the Philippines.

63. A Conjoint Analysis of Farmer Preferences for Community Forestry Contracts in the Sumber Jaya Watershed, Indonesia.

64. The highlands: a shared water tower in a changing climate and changing Asia

65. Eco-Certification: Can It Deliver Conservation and Development in the Tropics. 
66. Designing ecological and biodiversity sampling strategies. Towards mainstreaming climate change in grassland management.

67. Towards mainstreaming climate change in grassland management policies and practices on the Tibetan Plateau

68. An Assessment of the Potential for Carbon Finance in Rangelands

69 ECA Trade-offs Among Ecosystem Services in the Lake Victoria Basin.

69. The last remnants of mega biodiversity in West Java and Banten: an in-depth exploration of RaTA (Rapid Land Tenure Assessment) in Mount Halimun-Salak National Park Indonesia

70. Le business plan d'une petite entreprise rurale de production et de commercialisation des plants des arbres locaux. Cas de quatre pépinières rurales au Cameroun.

71. Les unités de transformation des produits forestiers non ligneux alimentaires au Cameroun. Diagnostic technique et stratégie de développement Honoré Tabuna et Ingratia Kayitavu.

72. Les exportateurs camerounais de safou (Dacryodes edulis) sur le marché sous régional et international. Profil, fonctionnement et stratégies de développement.

73. Impact of the Southeast Asian Network for Agroforestry Education (SEANAFE) on agroforestry education capacity.

74. Setting landscape conservation targets and promoting them through compatible land use in the Philippines.

75. Review of methods for researching multistrata systems.

76. Study on economic viability of Jatropha curcas L. plantations in Northern Tanzania assessing farmers' prospects via cost-benefit analysis

77. Cooperation in Agroforestry between Ministry of Forestry of Indonesia and International Center for Research in Agroforestry

78. "China's bioenergy future. an analysis through the Lens if Yunnan Province

79. Land tenure and agricultural productivity in Africa: A comparative analysis of the economics literature and recent policy strategies and reforms

80. Boundary organizations, objects and agents: linking knowledge with action in agroforestry watersheds

81. Reducing emissions from deforestation and forest degradation (REDD) in Indonesia: options and challenges for fair and efficient payment distribution mechanisms

2009

82. Mainstreaming climate change into agricultural education: challenges and perspectives

83. Challenging conventional mindsets and disconnects in conservation: the emerging role of eco-agriculture in Kenya's landscape mosaics

84. Lesson learned RATA garut dan bengkunat: suatu upaya membedah kebijakan pelepasan kawasan hutan dan redistribusi tanah bekas kawasan hutan

85. The emergence of forest land redistribution in Indonesia

86. Commercial opportunities for fruit in Malawi

87. Status of fruit production processing and marketing in Malawi

88. Fraud in tree science

89. Trees on farm: analysis of global extent and geographical patterns of agroforestry

90. The springs of Nyando: water, social organization and livelihoods in Western Kenya

91. Building capacity toward region-wide curriculum and teaching materials development in agroforestry education in Southeast Asia

92. Overview of biomass energy technology in rural Yunnan (Chinese - English abstract)

93. A pro-growth pathway for reducing net GHG emissions in China

94. Analysis of local livelihoods from past to present in the central Kalimantan Ex-Mega Rice Project area

95. Constraints and options to enhancing production of high quality feeds in dairy production in Kenya, Uganda and Rwanda 
2010

96. Agroforestry education in the Philippines: status report from the Southeast Asian Network for Agroforestry Education (SEANAFE)

97. Economic viability of Jatropha curcas L. plantations in Northern Tanzania- assessingfarmers' prospects via cost-benefit analysis.

98. Hot spot of emission and confusion: land tenure insecurity, contested policies and competing claims in the central Kalimantan Ex-Mega Rice Project area

99. Agroforestry competences and human resources needs in the Philippines

100. CES/COS/CIS paradigms for compensation and rewards to enhance environmental Services

101. Case study approach to region-wide curriculum and teaching materials development in agroforestry education in Southeast Asia

102. Stewardship agreement to reduce emissions from deforestation and degradation (REDD): Lubuk Beringin's Hutan Desa as the first village forest in Indonesia

103. Landscape dynamics over time and space from ecological perspective

104. Komoditisasi atau koinvestasi jasa lingkungan: skema imbal jasa lingkungan program peduli sungai di DAS Way Besai, Lampung, Indonesia

105. Improving smallholders' rubber quality in Lubuk Beringin, Bungo district, Jambi province, Indonesia: an initial analysis of the financial and social benefits

106. Rapid Carbon Stock Appraisal (RACSA) in Kalahan, Nueva Vizcaya, Philippines

107. Tree domestication by ICRAF and partners in the Peruvian Amazon: lessons learned and future prospects in the domain of the Amazon Initiative eco-regional program

108. Memorias del Taller Nacional: "Iniciativas para Reducir la Deforestación en la region Andino Amazónica", 09 de Abril del 2010. Proyecto REALU Peru

109. Percepciones sobre la Equidad y Eficiencia en la cadena de valor de REDD en Perú -Reporte de Talleres en Ucayali, San Martín y Loreto, 2009. Proyecto REALU-Perú.

110. Reducción de emisiones de todos los Usos del Suelo. Reporte del Proyecto REALU Perú Fase 1

111. Programa Alternativas a la Tumba-y-Quema (ASB) en el Perú. Informe Resumen y Síntesis de la Fase II. 2da. versión revisada

112. Estudio de las cadenas de abastecimiento de germoplasma forestal en la amazonía Boliviana

113. Biodiesel in the Amazon

114. Estudio de mercado de semillas forestales en la amazonía Colombiana

115. Estudio de las cadenas de abastecimiento de germoplasma forestal en Ecuador

116. How can systems thinking, social capital and social network analysis help programs achieve impact at scale?

117. Energy policies, forests and local communities in the Ucayali Region, Peruvian Amazon

118. NTFPs as a Source of Livelihood Diversification for Local Communities in the Batang Toru Orangutan Conservation Program

119. Studi Biodiversitas: Apakah agroforestry mampu mengkonservasi keanekaragaman hayati di DAS Konto?

120. Estimasi Karbon Tersimpan di Lahan-lahan Pertanian di DAS Konto, Jawa Timur

121. Implementasi Kaji Cepat Hidrologi (RHA) di Hulu DAS Brantas, Jawa Timur.

122. Kaji Cepat Hidrologi di Daerah Aliran Sungai Krueng Peusangan, NAD, Sumatra

123. A Study of Rapid Hydrological Appraisal in the Krueng Peusangan Watershed, NAD, Sumatra.

2011

124. An Assessment of farm timber value chains in Mt Kenya area, Kenya

125. A Comparative financial analysis of current land use systems and implications for the adoption of improved agroforestry in the East Usambaras, Tanzania

126. Agricultural monitoring and evaluation systems

127. Challenges and opportunities for collaborative landscape governance in the East Usambara Mountains, Tanzania

128. Transforming Knowledge to Enhance Integrated Natural Resource Management Research, Development and Advocacy in the Highlands of Eastern Africa 
129. Carbon-forestry projects in the Philippines: potential and challenges The Mt Kitanglad Range forestcarbon development

130. Carbon forestry projects in the Philippines: potential and challenges. The Arakan Forest Corridor forestcarbon project

131. Carbon-forestry projects in the Philippines: potential and challenges. The Laguna Lake Development Authority's forest-carbon development project

132. Carbon-forestry projects in the Philippines: potential and challenges. The Quirino forest-carbon development project in Sierra Madre Biodiversity Corridor

133. Carbon-forestry projects in the Philippines: potential and challenges. The Ikalahan ancestral domain forestcarbon development

134. The Importance of Local Traditional Institutions in the Management of Natural Resources in the Highlands of Eastern Africa

135. Socio-economic assessment of irrigation pilot projects in Rwanda

136. Performance of three rambutan varieties(Nephelium lappaceum L.) on various nursery media

137. Climate change adaptation and social protection in agroforestry systems: enhancing adaptive capacity and minimizing risk of drought in Zambia and Honduras

138. Does value chain development contribute to rural poverty reduction? Evidence of asset building by smallholder coffee producers in Nicaragua

139. Potential for biofuel feedstock in Kenya

140. Impact of fertilizer trees on maize production and food security in six districts of Malawi.

\section{2}

141. Fortalecimiento de capacidades para la gestión del Santuario Nacional Pampa Hermosa: Construyendo las bases para un manejo adaptativo para el desarrollo local. Memorias del Proyect

142. Understanding rural institutional strengthening: A cross-level policy and institutional framework for sustainable development in Kenya

143. Climate change vulnerability of agroforestry

144. Rapid assesment of the inner Niger delta of Mali

145. Designing an incentive program to reduce on-farm deforestationin the East Usambara Mountains, Tanzania

146. Extent of adoption of conservation agriculture and agroforestry in Africa: the case of Tanzania, Kenya, Ghana, and Zambia

147. Policy incentives for scaling up conservation agriculture with trees in Africa: the case of Tanzania, Kenya, Ghana and Zambia

148. Commoditized or co-invested environmental services? Rewards for environmental services scheme: River Care program Way Besai watershed, Lampung, Indonesia.

149. Assessment of the headwaters of the Blue Nile in Ethiopia.

150. Assessment of the uThukela Watershed, Kwazaulu.

151. Assessment of the Oum Zessar Watershed of Tunisia.

152. Assessment of the Ruwenzori Mountains in Uganda.

153. History of agroforestry research and development in Viet Nam. Analysis of research, opportunities and gaps.

154. REDD+ in Indonesia: a Historical Perspective

155. Agroforestry and Forestry in Sulawesi series: Livelihood strategies and land use system dynamics in South Sulawesi

156. Agroforestry and Forestry in Sulawesi series: Livelihood strategies and land use system dynamics in Southeast Sulawesi.

157. Agroforestry and Forestry in Sulawesi series: Profitability and land-use systems in South and Southeast Sulawesi.

158. Agroforestry and Forestry in Sulawesi series: Gender, livelihoods and land in South and Southeast Sulawesi 
159. Agroforestry and Forestry in Sulawesi series: Agroforestry extension needs at the community level in AgFor project sites in South and Southeast Sulawesi, Indonesia.

160. Agroforestry and Forestry in Sulawesi series: Rapid market appraisal of agricultural, plantation and forestry commodities in South and Southeast Sulawesi.

2013

161. Diagnosis of farming systems in the Agroforestry for Livelihoods of Smallholder farmers in Northwestern Viet Nam project

162. Ecosystem vulnerability to climate change: a literature review

163. Local capacity for implementing payments for environmental services schemes: lessons from the RUPES project in northeastern Viet Nam

164. Seri Agroforestri dan Kehutanan di Sulawesi: Agroforestry dan Kehutanan di Sulawesi: Strategi mata pencaharian dan dinamika sistem penggunaan lahan di Sulawesi Selatan

165. Seri Agroforestri dan Kehutanan di Sulawesi: Mata pencaharian dan dinamika sistem penggunaan lahan di Sulawesi Tenggara

166. Seri Agroforestri dan Kehutanan di Sulawesi: Profitabilitas sistem penggunaan lahan di Sulawesi Selatan dan Sulawesi Tenggara

167. Seri Agroforestri dan Kehutanan di Sulawesi: Gender, mata pencarian dan lahan di Sulawesi Selatan dan Sulawesi Tenggara

168. Seri Agroforestri dan Kehutanan di Sulawesi: Kebutuhan penyuluhan agroforestri pada tingkat masyarakat di lokasi proyek AgFor di Sulawesi Selatan dan Tenggara, Indonesia

169. Seri Agroforestri dan Kehutanan di Sulawesi: Laporan hasil penilaian cepat untuk komoditas pertanian, perkebunan dan kehutanan di Sulawesi Selatan dan Tenggara

170. Agroforestry, food and nutritional security

171. Stakeholder Preferences over Rewards for Ecosystem Services: Implications for a REDD+ Benefit Distribution System in Viet Nam

172. Payments for ecosystem services schemes: project-level insights on benefits for ecosystems and the rural poor

173. Good practices for smallholder teak plantations: keys to success

174. Market analysis of selected agroforestry products in the Vision for Change Project intervention Zone, Côte d'Ivoire

175. Rattan futures in Katingan: why do smallholders abandon or keep their gardens in Indonesia's 'rattan district'?

176. Management along a gradient: the case of Southeast Sulawesi's cacao production landscapes

2014

177. Are trees buffering ecosystems and livelihoods in agricultural landscapes of the Lower Mekong Basin? Consequences for climate-change adaptation

178. Agroforestry, livestock, fodder production and climate change adaptation and mitigation in East Africa: issues and options

179. Trees on farms: an update and reanalysis of agroforestry's global extent and socio-ecological characteristics 

The World Agroforestry Centre is an autonomous, non-profit research organization whose vision is a rural transformation in the developing world as smallholder households increase their use of trees in agricultural landscapes to improve food security, nutrition, income, health, shelter, social cohesion, energy resources and environmental sustainability. The Centre generates science-based knowledge about the diverse roles that trees play in agricultural landscapes, and uses its research to advance policies and practices, and their implementation that benefit the poor and the environment. It aims to ensure that all this is achieved by enhancing the quality of its science work, increasing operational efficiency, building and maintaining strong partnerships, accelerating the use and impact of its research, and promoting greater cohesion, interdependence and alignment within the organization.

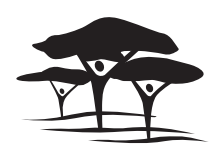

United Nations Avenue, Gigiri • PO Box 30677 • Nairobi, $00100 \cdot$ Kenya Telephone: +254 207224000 or via USA +1 6508336645 Fax: +254207224001 or via USA +1 6508336646 Email: worldagroforestry@cgiar.org•www.worldagroforestry.org

Southeast Asia Regional Program • Sindang Barang • Bogor 16680 PO Box $161 \cdot$ Bogor $16001 \cdot$ Indonesia

Telephone: +62 $2518625415 \cdot$ Fax: +62 2518625416 